2019-04-15

\title{
Aliphatic amines at the Cape Verde Atmospheric Observatory: abundance, origins and sea-air fluxes
}

Fitzsimons, Mark

http://hdl.handle.net/10026.1/13318

10.1016/j.atmosenv.2019.02.011

Atmospheric Environment

Elsevier

All content in PEARL is protected by copyright law. Author manuscripts are made available in accordance with publisher policies. Please cite only the published version using the details provided on the item record or document. In the absence of an open licence (e.g. Creative Commons), permissions for further reuse of content should be sought from the publisher or author. 
Post-print version

DOI: 10.1016/j.atmosenv.2019.02.011

Accepted: 6th February 2019

Embargo period: 24 months

\section{Aliphatic amines at the Cape Verde Atmospheric Observatory: abundance, origins and sea-air fluxes}

Manuela van Pinxteren ${ }^{l}$, Khanneh Wadinga Fomba ${ }^{1}$, Dominik van Pinxteren ${ }^{l}$, Nadja Triesch ${ }^{1}$, Erik Hans Hoffmann ${ }^{1}$, Charlotte H. L. Cree ${ }^{2}$, Mark F. Fitzsimons ${ }^{2}$, Wolf von Tümpling ${ }^{3}$, Hartmut Herrmann ${ }^{1 *}$

${ }^{1}$ Leibniz Institute for Tropospheric Research (TROPOS), Atmospheric Chemistry Department (ACD), Permoserstr. 15, 04318 Leipzig, Germany

${ }^{2}$ Biogeochemistry Research Centre, Marine Institute, Plymouth PL4 8AA, UK

${ }^{3}$ Helmholtz Centre for Environmental Research - UFZ Brückstraße 3a, 39114 Magdeburg, Germany

Submitted to:

Atmospheric Environment

$10 / 2018$

*Corresponding author

Tel.: +49-(0)341 27177024

Fax: +49-(0)341 2717997024

E-mail: herrmann@tropos.de

Abstract 
Aliphatic amines are important constituents of the marine environment. However, their biogenic origins, formation processes and roles in atmospheric chemistry are still not well understood. Here we present measurements of monomethylamine (MMA), dimethylamine (DMA) and diethylamine (DEA) from two intensive sampling campaigns at the Cape Verde Atmospheric Observatory (CVAO), a remote marine station in the tropical Atlantic Ocean. The amines were measured in the sea surface microlayer (SML), in bulk seawater, in the gas and the submicron particulate aerosol phase. Additionally, a 24-month record of amine concentrations in aerosol particles, together with other particle constituents and biological and meteorological parameters, is presented. In the SML, mean amine concentrations were in the range $20-50 \mathrm{nmol} \mathrm{L}^{-1}$. The correlation of the amines to chlorophyll-a $\left(\mathrm{R}^{2}=0.52\right)$ and the abundance of the diatom pigment fucoxanthin may indicate that amines were formed via algal production. Amine concentrations in the gas and particulate aerosol phases were dominated by DMA, with average concentrations of $4.5 \mathrm{ng} \mathrm{m}^{-3}$ and $5.6 \mathrm{ng} \mathrm{m}^{-3}$, respectively. Average MMA concentrations were $0.8 \mathrm{ng} \mathrm{m}^{-3}$ in the gas phase and $0.2 \mathrm{ng} \mathrm{m}^{-3}$ in the particle phase. DEA was present in the particle phase with an average concentration of $3.9 \mathrm{ng} \mathrm{m}^{-3}$, but was not detected in the gas phase. Sea to air fluxes for MMA and DMA were calculated from the seawater and gaseous amine concentrations; these varied from -8.7 E-14 to +4.0 E-13 mol m $\mathrm{m}^{-2} \mathrm{~s}^{-1}$ and from 1.9 E-12 to $+2.17 \mathrm{E}-12 \mathrm{~mol} \mathrm{~m}^{-2} \mathrm{~s}^{-1}$, respectively. While the flux for MMA was mainly positive, suggesting an oceanic source for this analyte, the flux for DMA could be both positive and negative, indicating that 2-way transport may be occurring. Principal component analysis of the 24-month dataset of amines in aerosol particles revealed that the particulate amines were not directly linked to the identified sources. It seems that the transfer of amines was being determined by gas to particle conversion rather than via primary processes. The correlation of both seawater- and gas phase- amines with biological indicators suggests that they were partly linked and that the amine abundance in the atmosphere (gas phase) reflected biological processes in seawater. In contrast, particulate amine concentrations did not show such a direct response and might have other significant sources and environmental drivers.

Keywords: amines, marine atmosphere, sea surface microlayer, aerosol particles, sea-air-flux

\section{Introduction}


Aliphatic amines are dynamic organic nitrogen compounds; they are ubiquitous in the marine environment. Several studies have identified approximately 150 amines in the atmosphere and demonstrate that the ocean is a very important natural source for these volatile compounds (Ge et al., 2011a, b; Lee and Wexler, 2013).

Amines can be produced and consumed by different kinds of phytoplankton and bacteria (references in Gibb et al, 1999a). They are released via direct emission from phytoplankton as well as via degradation of organic matter that contains proteins, amino acids or other nitrogenbearing compounds (King, 1988). Additionally, biological degradation of quaternary nitrogen osmolytes $\left(\mathrm{R}_{4} \mathrm{~N}^{+}\right.$, where $\mathrm{R}$ is an alkyl substituent on the $\mathrm{N}$ atom) is proposed as a major source of methylamines in seawater (Beale and Airs, 2016). These osmolytes, such as glycine betaine (GBT), trimethylamine N-oxide (TMAO) and choline are produced by marine organisms to maintain osmotic pressure (Burg and Ferraris, 2008). Once released from phytoplankton cells to the environment by passive diffusion, during 'sloppy' grazing, or through cell lysis, they can be degraded by bacteria to trimethylamine and further modified to less-substituted methylamines. Pathways for the degradation of nitrogen osmolytes are starting to be elucidated. Model organisms of the marine roseobacter clade (MRC) have been shown to grow on choline and GBT as their sole carbon source, resulting in remineralisation to ammonia (Lidbury et al., 2015a), whilst MRC have also been shown to use TMAO as an energy resource (Lidbury et al., 2015b). The degradation of TMAO has also been demonstrated in members of the Pelagibacterales bacteria (SAR11 clade) (Lidbury et al., 2014). In addition, marine metagenomics data-mining has identified the presence of genes encoding the production of trimethylamine from nitrogen osmolytes in the open ocean (Jameson et al., 2016). The methylated amines, mono- di- and trimethylamine (MMA, DMA and TMA, respectively), can provide a source of carbon and nitrogen for marine microorganisms (Taubert et al., 2017). Recent studies show that heterotrophic bacteria utilize methylamines (specifically TMA) as a supplementary energy source (Lidbury et al., 2015b).

In seawater, although the solvated amine cation typically accounts for more than $90 \%$ of the total dissolved amine concentration, the exchange of gaseous methylamines across the sea-air interface is likely to represent an important loss from the aqueous cycle, as reduced nitrogen is an essential nutrient. The oceanic export of the methyl amines may constitute a potentially important source of basic compounds to the remote atmosphere (Gibb et al., 1999a; Almeida et al., 2013). However, these fluxes are currently poorly characterized, which makes their impact on atmospheric composition uncertain.

In the atmosphere, the high vapour pressure of the molecular weight amines explains their presence in the atmospheric gas phase. However, according to their thermodynamic properties, amines are likely to form aminium salts with atmospheric acids resulting in the formation of secondary aerosol mass (Ge et al., 2011a). They are highly water-soluble with an acid dissociation constant ( $\mathrm{pKa}$ ) around 10 (Christensen et al., 1969) and can partition into acidic particles and neutralize them. In laboratory studies, amines displaced ammonium from inorganic salts to form aminium salts (Kurten et al., 2008). The degree to which the amines are scavenged by aqueous aerosol particles is likely dependent on the $\mathrm{pK} a$ of the amine and the relative humidity. Recent laboratory studies underline the importance of amines in new particle formation as a function of water vapor and the concentration of gaseous precursors. It was shown that, despite being 1 to 3 orders of magnitude less abundant than ammonia, amines could 
still drive new particle formation (Chen et al., 2015; 2016). Furthermore, aliphatic amines have a higher nucleation capability with sulfuric acid than ammonium (Glasoe et al., 2015) and have high potential to stabilize sulfuric acid clusters (Jen et al., 2014). Pratt et al., (2009) investigated seasonal dependencies of ambient particle phase amines and found a strong seasonal variation in gas to particle partitioning of alkyl amines suggesting that the acidity of the particles greatly affected the gas to particle partitioning of amine species. Cape et al., (2011) reviewed sources and methods for the determination of organic nitrogen in the atmosphere. Dall'Osto et al., (2017) underlined that organic nitrogen represents a large fraction of total airborne nitrogen in gas particles and dissolved phases, where aliphatic amines are of interest due to their possible key role in nucleation (Kurten et al., 2008). In size-resolved field measurements over the ocean, the highest amine concentrations were detected in sub-micrometer particles (Facchini et al., 2008; Müller et al., 2009), and contributed a significant amount to marine aerosol mass of up to $11 \%$. These observations correspond with the outcome of theoretical considerations indicating that aliphatic amines could form new particles, similar to ammonia. Amine measurements at Mace Head, Ireland (Facchini et al., 2008) varied seasonally, correlating with other marine biogenic compounds, such as methane sulfonic acid, a dimethylsulfide oxidation intermediate, or non-sea-salt sulfate ( $\mathrm{nss} \mathrm{SO}_{4}{ }^{2-}$ ). As such, the amines were assumed to be of marine biogenic origins. A link between particulate amine occurrence and biological formation processes was identified in the remote Atlantic Ocean (Müller et al., 2009; van Pinxteren et al., 2015) and in the Pacific Ocean (Yu et al., 2016; Xie et al., 2018). Additionally, Finessi et al. (2012) identified marine sources for amines on aerosol particles. Dall'Osto et al. (2012) proposed nitrogenated and aliphatic organic vapors of marine origin (including aliphatic amines) as possible drivers for marine secondary organic aerosol growth. Miyazaki et al., (2010) found that organic nitrogen and carbon were twice as abundant in aerosols collected in an oceanic region with higher biological productivity compared to regions with lower productivity. They underlined that the enrichment of organic nitrogen was likely linked to oceanic biological activity and that the sea surface was a source of organic nitrogen to remote marine air.

Despite these findings, there are few measurements, especially on longer time scales, of amine concentrations in the remote ocean to determine the roles of these small volatile basic compounds in atmospheric processes, in addition to knowledge of their biogenic origins and the formation processes. Most recent studies lack parallel measurements of the amines in the different marine phases as few have been conducted simultaneously on both aerosol particle and gas phase amines in pristine marine regions.

The aim of this work was to investigate the abundance, origins and air-sea fluxes of the low molecular weight aliphatic amines, namely MMA, DMA and diethylamine (DEA), as well as their tendency to convert to the particle phase. Furthermore, we aimed to improve understanding of the importance of oceanic bio-productivity and meteorological parameters to amine formation. Concerted field measurements were performed, comprising measurements of the amines in oceanic seawater (bulk water and sea surface microlayer, SML), in the gas phase and in the submicron particulate phase, in a remote marine environment. Finally, long-term measurements over a 24-month time series of amine concentrations in submicron aerosol particles were performed to elucidate sources and characteristics of these compounds.

\section{Experiment}




\subsection{Sampling site}

Field experiments were performed at the Cape Verde Atmospheric Observatory (CVAO), a remote marine station in the tropical Atlantic Ocean, situated on the island of Sao

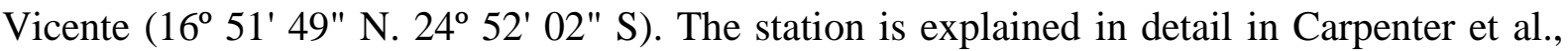
(2010) and Fomba et al., (2014). During winter (December - February) the CVAO is primarily influenced by desert dust, with air masses coming from the Saharan, while from spring till autumn the air masses mainly originate from the open sea (northeastern inflow). At the CVAO, year-round sampling of aerosol particles is performed with different instruments. During November 2011 and November 2013, two intensive campaigns for seawater sampling and gas phase sampling were carried out.

\subsubsection{SML and bulkwater sampling}

Water was sampled on board a fishing boat, within a distance of about $2 \mathrm{~km}$ from the CVAO. The SML was sampled using the glass plate approach (Cunliffe and Wurl, 2014). A glass plate with a sampling area of $2000 \mathrm{~cm}^{2}$ was vertically immersed in the water and slowly drawn upwards. The film that is attached to the surface of the glass was taken off with a framed Teflon wiper directly into a bottle (van Pinxteren et al., 2017). A uniform withdrawal rate of about $10 \mathrm{~cm} \mathrm{~s}^{-1}$ was consistently applied. Bulk seawater was sampled from a depth of $1 \mathrm{~m}$ into a glass bottle mounted on a telescopic rod. The bottle was opened underwater to avoid influences from the SML during bulk water sampling. A fraction of each bulk water sample (1$5 \mathrm{~L}$ ) was filtered through Whatman GF-F filters (pore size: $0.7 \mu \mathrm{m}$ ) for pigment analysis (chla and fucoxanthin). All water samples were stored in glass bottles at $-20{ }^{\circ} \mathrm{C}$ before analysis. Blank samples were collected by loading reagent water into bottles (the same kind used for the purpose of bulk water/SML sampling). These bottles were taken to the field and subjected to the same procedures applied to the field samples, such as filtering and freezing. All materials were pre-cleaned extensively using a $10 \% \mathrm{HCl}$ solution and high purity water. Within the two campaigns, 14 samples (7 SML and 7 bulk water) were obtained.

\subsubsection{Aerosol particle sampling}

The aerosol sampler was installed at the CVAO at a height of $30 \mathrm{~m}$ on top of a tower located directly at the coast. The sampling of aerosol particles for amine analysis was conducted using a low volume sampler $\left(\mathrm{PM}_{1}\right)$ equipped with $47 \mathrm{~mm}$ PTFE filters (Fiberfilm Wicom, Heppenheim, Germany). Additional particle sampling at the CVAO station was performed using a high-volume Digitel sampler DHA-80 (Walter Riemer Messtechnik. Germany). Aerosol particles $\left(\mathrm{PM}_{1}\right)$ were collected on preheated $150 \mathrm{~mm}$ quartz fiber filters (Minktell. MK 360) at a flow rate of $700 \mathrm{~L} \mathrm{~min}^{-1}$. Sampling time was $24 \mathrm{~h}$ from 12:00 to 12:00 (UTC). After sampling, filters were stored in aluminum boxes at $-20^{\circ} \mathrm{C}$ and transported in a cooling container $\left(-20{ }^{\circ} \mathrm{C}\right)$ to the TROPOS laboratories in Leipzig, Germany.

\subsubsection{Gas phase sampling}


The gas sampling device consisted of a gas/aerosol particle sampling filter pack. It was designed according to the filter pack described by Gibb et al., (1999a) and consisted of a PTFE filter for aerosol particle sampling and a paper filter coated with $0.01 \mathrm{M}$ oxalic acid for gaseous amine sampling. The filters were arranged as illustrated in Figure 1. A PTFE net was used to separate the aerosol particle filter and the gas filter. In addition to the filter pack, a "background" filter pack was deployed also consisting of an aerosol particle filter and an acidified gas filter but subject to zero gas flow. After probing, the filters were stored and transported at $-20{ }^{\circ} \mathrm{C}$ and analyzed in the laboratories of TROPOS. Breakthrough was tested by attaching a second acidified paper filter behind the paper filter in order to investigate whether the amines were entirely captured on the first filter. The second paper filter was free of amines, and it was assumed that all gaseous amines were retained on the first filter. The number of extraction steps needed to extract the maximum concentration of analytes to the filter was tested, where a second extraction step on the same filters was performed. No analytes were found in the second extract and complete extraction in the first step was assumed. Quinn et al., (1990) performed intercomparison studies of the filter pack systems and showed that at ambient temperature (20-25 ${ }^{\circ} \mathrm{C}$ ) and high relative humidity $(75 \%)$, conditions similar to those at the Cape Verde islands, the acid coated filters had a collection efficiency for ammonium close to $100 \%$. Due to the greater relative basicity of the amines, it was assumed that the acid-base mode of amine sampling was at least as efficient as for ammonium (Gibb et al., 1999a).

\subsubsection{Amine measurements in seawater}

Analytical measurements of aliphatic amines in the SML and in bulk water were performed using ultra high performance liquid chromatography with electrospray ionization and Orbitrap mass spectrometry (UHPLC/ESI-Orbtitrap-MS). To this end, a UHPLC system (Vanquish Horizon UHPLC system, Thermo Fisher Scientific ${ }^{\mathrm{TM}}$, Waltham, Massachusetts, USA) was coupled to an ESI-Orbitrap mass spectometer (Q Exactive ${ }^{\mathrm{TM}}$ plus, Thermo Fisher Scientific ${ }^{\mathrm{TM}}$, Waltham, Massachusetts, USA), applying detection in positive mode. The separation was carried out on an ACQUITY UPLC $®$ HSS T3 column (Waters, Eschborn, Germany) with the following dimensions: $1.8 \mu \mathrm{m}, 2.1 \times 100 \mathrm{~mm}$ at $30{ }^{\circ} \mathrm{C}$. The eluent composition was (A) 0.2 vol\% acetic acid in high purity water (Millipore Elix 3 and Element A10, Merck Millipore, Darmstadt, Germany) and (B) Acetonitrile (Optima® LC/MS Grade, Fisher Scientific, Hampton, New Hampshire, USA) and the separation was performed at a flow rate of $0.3 \mathrm{~mL} \mathrm{~min}^{-1}$. The eluent gradient program was as follows: $5 \% \mathrm{~B}$ for $1 \mathrm{~min}, 5 \% \mathrm{~B}$ to $100 \% \mathrm{~B}$ in $16 \mathrm{~min}, 100 \% \mathrm{~B}$ held for $2 \mathrm{~min}$, in $0.1 \mathrm{~min}$ back to $5 \% \mathrm{~B}$ and held for $3.9 \mathrm{~min}$. The duration of one analysis was $21 \mathrm{~min}$. Before analysis, the sample underwent a preparation procedure comprising desalination, an enrichment and derivatization steps. For desalination, 32 $\mathrm{mL}$ of the SML samples or $48 \mathrm{~mL}$ of the bulk water samples were desalinated using Dionex ${ }^{\mathrm{TM}}$ OnGuard $^{\mathrm{TM} I I} \mathrm{Ag} / \mathrm{H}$ cartridges (Thermo Fisher Scientific ${ }^{\mathrm{TM}}$, Waltham, Massachusetts, USA). The volume of desalinated samples was reduced using a vacuum concentrator at $\mathrm{T}=30^{\circ} \mathrm{C}$ to several $\mu \mathrm{L}$ (miVac sample Duo, GeneVac Ltd., Ipswich, United Kingdom) and reconstituted in hugh purity water and filterd using $0.2 \mu \mathrm{m}$ syringe filters (Acrodisc-GHP; $25 \mathrm{~mm}$, Pall Corporation, New York, USA). The amines were derivatized using an AccQ-Tag ${ }^{\mathrm{TM}}$ precolumn 
derivatization method (Waters, Eschborn, Germany) as described in Müller et al., (2009). Amines concentrations were calculated via external calibration, with each sample measured in duplicate, and all values were corrected for field blanks.

Further analyses of water samples were performed at the University of Plymouth, UK, using solid phase microextraction, gas chromatogpaphy and nitrogen phosphorous detection (SPME-GC-NPD) according to Cree et al., (2018). In brief, $850 \mathrm{~mL}$ of the acidified filtered sample was adjusted to $\mathrm{pH} 13.4$ with sodium hydroxide solution $(10 \mathrm{M})$ to convert the amines to their gaseous form. The volumetric flask was then immediately closed with a Suba-seal and the SPME fibre inserted to the headspace of the sample. A mixture of polydimethylsiloxane and divinylbenzene (PDMS-DVB) served as the SPME fiber coating and effective extraction material for the amines. After stirring for 2.5 hours at $60{ }^{\circ} \mathrm{C}$, the SPME fiber was removed then inserted into a GC injector for analyte separation on a CP-Volamine column. The analytes were detected using a nitrogen-phosphorus detector (NPD), a selective and sensitive detection method for nitrogen-containing compounds.

\subsubsection{Amine measurements in the gas and particle phase}

For amine analysis in the gas and particle phase, the PTFE filters (particulate amines) and the coated paper filters (gas phase amines) were extracted in deionised water by shaking for $2 \mathrm{~h}$ and measured on an ion chromatography (IC) system (ICS3000, Dionex, Sunnyvale, CA, USA) equipped with an IonPac CG16 guard column (3 x $50 \mathrm{~mm})$ and an IonPac CS16 separation column $(3 \times 250 \mathrm{~mm})$ at $60^{\circ} \mathrm{C}$. Separation was achieved using a gradient of methane sulfonic acid, at an initial concentration of $6 \mathrm{mM}$ increasing to $15 \mathrm{mM}(20 \mathrm{~min})$ then $30 \mathrm{mM}$ (30 min), and finally to $50 \mathrm{mM}$ (31 min), which was held until the end of the IC run (42 min) (a more detailed account can be found in van Pinxteren et al., (2015)). Field blanks were obtained by inserting the filters into the sampler for a duration of 24 hours without loading them. Three field blanks were collected during the course of each campaign. The filter concentrations for the coated paper phase filters (gas phase amines) were blank-corrected, with blank values typically below $10 \%$ of the filter concentrations. The amine concentrations in the PTFE filters blanks were below the detection limits of the methods.

From the quartz fiber filters, analysis of organic carbon (OC), elemental carbon (EC), water soluble organic carbon (WSOC) and the main inorganic ions calcium, sodium, sulfate, chloride, and nitrate was performed as described in Müller et al., (2010) and van Pinxteren et al., (2015; 2017).

Amine concentrations in all seawater and atmospheric phases were correlated to a number of different variables to elucidate their possible origins. If not stated otherwise, all reported correlations were statistically significant at a significance level of $\alpha=0.05$.

\subsection{Chl-a, pigment and wind data}

Chl-a is a commonly applied indicator for describing biological activity in the surface ocean (O'Dowd et al., 2004; de Leeuw et al., 2011). Chl-a values can be estimated from satellite retrievals as well as from seawater measurements. During the intensive campaigns, when 
seawater sampling was performed, concentrations of chl-a and other pigments (fucoxanthin, phaeophytin and lutein) were measured using HPLC with fluorescence detection (Dionex, Sunnyvale, CA. USA). Briefly, GF-F filters were extracted in $5 \mathrm{~mL}$ ethanol, and $20 \mu \mathrm{L}$ aliquots of the extract were injected into the HPLC and the pigments separated under gradient elution using methanol/acetonitrile/water systems as mobile phase solvents. For the interpretation of biological productivity during the 24-month time series, chl-a concentrations were also obtained from satellite retrievals provided by the Ocean Color Web operated by the NASA (http://oceancolor.gsfc.nasa.gov/. 30.07.18). The concentrations were obtained using MODISAQUA and MODIS-TERRA within a radius of $1^{\circ}$ from the sampling location and then averaged in order to fill data gaps due to cloud coverage.

Wind speed measurements were achieved from the Davis weather station at the CVAO tower, provided by the BADC portal (http://data.ceda.ac.uk/badc/capeverde/data/cv-met-davis/.30.07.18).

\subsection{Back trajectories}

Information regarding air mass origins was derived from back trajectory analyses. Seven-day back trajectories were calculated hourly within the sampling intervals using the NOAA HYSPLIT (HYbrid Single-Particle Lagrangian Integrated Trajectory model (Draxier and Hess, 1998 and refs. therein) in the ensemble mode with an arrival height of $500 \pm 250 \mathrm{~m}$ (van Pinxteren et al., 2010).

\subsection{Calculation of amine sea-air fluxes}

A commonly applied procedure to calculate the flux of a trace gas across the sea-air interface is the application of a 'two-phase' resistance model of gas exchange (Liss and Slater, 1974). This model includes the measured concentration gradient of the trace gas across the interface, and the transfer velocity. The mass flux $F\left(\mathrm{~mol} \mathrm{~m}^{-2} \mathrm{~s}^{-1}\right)$ of a certain trace gas across the sea-air interface was expressed according to Equations 1 and 2:

$F=k_{t}\left(c_{w}-c_{g} / H\right)$

with

$\frac{1}{k_{t}}=\frac{1}{k_{w}}+1 / H k_{a}$

Where $C_{w}$ and $C_{g}$ are the seawater and gaseous concentrations, respectively. The seawater concentration requires free gaseous dissolved aliphatic amines. MMA and DMA have $\mathrm{p} K_{a}$ values of 10.64 and 10.73, respectively (Christensen et al., 1969). At the $\mathrm{pH}$ of seawater (7.8 to 8.2), most of the dissolved MMA and DMA in seawater is protonated. The non-protonated seawater concentration was calculated for pure water by Equation 3:

$C_{w}=C_{t o t} \times 10\left(\frac{\mathrm{pH}_{\text {sea }}-p K_{a}}{1+10^{p H_{\text {sea }}-p K_{a}}}\right)$ 
Where the parameter $C_{t o t}$ represents the measured concentration as the sum of non-protonated and protonated amine form. From this approach, $0.4 \%$ and $0.3 \%$ of MMA and DMA were nonprotonated, respectively. The effect of salinity was not measured and therefore not considered. However, assuming the calculation method of Gibb et al., (1999a) with a salinity of 36 PSU the non-protonated ratio ranged for MMA from $0.29 \%$ to $0.32 \%$ and for DMA from $0.24 \%$ to $0.26 \%$ from $10{ }^{\circ} \mathrm{C}$ to $28{ }^{\circ} \mathrm{C}$. Consequently, the calculated values in this study represent upper limits but are close to reality. $H$ is the dimensionless gas- over-liquid form of the Henry's law constant. The parameters $k_{t}, k_{w}$ and $k_{a}$ are the respective total, liquid and air mass transfer coefficients $\left(\mathrm{m} \mathrm{s}^{-1}\right)$. The inverse of $k_{w}$ and $k_{a}$ are the respective water-side and air-side resistances. Both transfer coefficients were calculated according to the preferred parameterizations (Equation 4) described in detail by Carpenter et al., (2012). The water side resistance $k_{w}$ was calculated according to the approach of Nightingale et al., (2000).

$\left.k_{w}\left(\mathrm{~cm} \mathrm{hr}^{-1}\right)=\left(0.222 u_{10}^{2}+0.333 u_{10}\right)\left(\frac{s_{c w}}{600}\right)^{-1 / 2}\right)$

Where $\mathrm{u}_{10}$ is the wind speed $\left(\mathrm{m} \mathrm{s}^{-1}\right)$ at $10 \mathrm{~m}$ and $S_{C w}$ is the Schmidt number of the gas of interest in water. $S_{C w}$ was calculated according to Equation 5 with the parameterisation given in Khalil et al., (1999).

$S_{C w}=335.6 \mathrm{M}^{1 / 2}\left(1-0.065 \mathrm{~T}+0.002043 \mathrm{~T}^{2}+0.000026 \mathrm{~T}^{3}\right)$

The air side resistance $k_{a}$ was calculated according to Equation 6 from Johnson, (2010).

$k_{a}=1 \times 10^{-3}+\frac{\mathrm{u}^{*}}{13.3 \times \mathrm{S}_{\mathrm{Ca}}^{1 / 2}+\mathrm{C}_{\mathrm{D}}^{-1 / 2}+5+\frac{\ln \left(\mathrm{S}_{\mathrm{ca}}\right)}{2 \mathrm{~K}}}$

The coefficient $\mathrm{u}^{*}$ is the friction velocity, $S_{C a}$ is the Schmidt number of the gas of interest in the air, $C_{D}$ is the drag coefficient and $\kappa$ is the Karman constant, which typically has a value of 0.4 in air (Carpenter et al., 2012). The required diffusion coefficient of the gas in air to calculate $S_{C a}$ is calculated according to the approach of Fuller et al., (1966). The friction velocity $u^{*}$ is related to the wind speed by the drag coefficient $C_{D}$ and defined as follows in Equation 7:

$c_{D}=\left(\frac{u^{*}}{u_{10}}\right)^{2}$

The drag coefficient was calculated following the formulation of Johnson (2010) in Equation 8 .

$10^{3} c_{D}=0.61+0.063 \times u_{10}$

The reorganisation of (8) and insertion into (7) leads to $u^{*}$. Further physicochemical parameters of MMA and DMA used for the calculations in this study are given in the SI (Table S1). 


\section{Results and Discussion}

\subsection{Intensive campaigns in November 2011 and 2013}

\subsubsection{Amines in seawater}

Table 1 presents the concentrations of the amines in the SML and in the bulk water. The amines were present in the SML samples in the nmol $\mathrm{L}^{-1}$ range, with two outliers showing higher concentrations of DMA on the 12 and 19 of November, 2013, that were confirmed by replicate analysis (standard deviations below 20\%). In most of the corresponding bulk water samples, the amines were not detected. For all data, the concentration of amines in the SML was quite similar (average: 19 to $53 \mathrm{nmol} \mathrm{L}{ }^{-1}$; median: 11 to $22 \mathrm{nmol} \mathrm{L}^{-1}$ ). For the two intensive campaigns in 2011 and 2013, the average concentration of MMA was reasonably constant at $19 \mathrm{nmol} \mathrm{L}-1$ (min.: $5 \mathrm{nmol} \mathrm{L}{ }^{-1}$, max.: $33 \mathrm{nmol} \mathrm{L}^{-1}$ ). Greater variability was observed for DMA (average $53 \mathrm{nmol} \mathrm{L}{ }^{-1}$, min.: $2 \mathrm{nmol} \mathrm{L}-1$, max.: $197 \mathrm{nmol} \mathrm{L}^{-1}$ ) with higher variations in 2013. Significant concentration differences were, however, only detected for DEA within the two campaigns (one-way anova, $p=0.003$ ). In 2011 the DEA concentrations were twice as high as in 2013 (22 vs. $\left.11 \mathrm{nmol} \mathrm{L}^{-1}\right)$.

The concentrations of the amines were at the same order of magnitude, though on the upper end, compared to measurements from other marine stations, such as the Arabian Sea (Gibb et al., 1999a) or the Baltic Sea (van Pinxteren et al., 2012).

As only one out of seven bulkwater sample contained amines at detectable concentrations (Table1), it can be concluded that those concentrations were not representative of the underlying water in this area. Bulk water concentrations appeared to be much below the SML concentrations. This finding could be explained by the strong enriching capabilities of the SML for nitrogen-containing compounds (e.g. Reinthaler et al., 2008). It is also possible that amines are formed in the SML.

In the present study, the amine concentrations showed a correlation with chl-a $\left(R^{2}=\right.$ 0.53 , Fig. S1a), which is applied as a broad indicator of biological activity. To elucidate further phytoplankton groups, we additionally measured the pigments fucoxanthin, phaeophytin and lutein. Among these pigments, only fucoxanthin was detected; it showed a weak positive correlation with the amines in the SML $\left(R^{2}=0.26\right.$, Fig S1b). Fucoxanthin belongs to the group of xanthophylls and, in addition to chl-a, fucoxanthin acts as a dye in the chloroplasts of diatoms and can, therefore, be regarded as a marker for diatoms (Cantonati et al., 2009). It should noted that both the correlations of amines with chl-a and fucoxanthin were based on a small number of data points (i.e. $\mathrm{n}=6$ or 7 ). With p-values of 0.06 and 0.30 , respectively, they were statistically not significant at a significance level of $\alpha=0.05$. However, the visual trend observed in Fig. S1 is an indication that the amines might be formed through algal production dynamics, as also suggested by Gibb et al., (1999b), and are therefore partly linked to oceanic bioproduction. Clearly, more data are needed to support this hypothesis.

The methylamine precursor, glycine betaine (GBT), has been measured previously over a seasonal cycle, in the English Channel, and a positive correlation with chl-a was observed. Cree (2014) found that 7 of 10 primary pigments also correlated positively with GBT, including fucoxanthin, while a close relationship of both GBT and chl-a with phytoplankton carbon was observed. Although bacteria may be the primary source of methylamines in the water column 
(Lidbury et al., 2014; Lidbury et al., 2015a; 2015b; Jameson et al., 2016), their short residence time (Cree et al., 2018) indicates that both phytoplankton and bacteria play a role in methylamine abundance and dynamics.

Regarding the biological cycling of amines, Steiner and Hartmann, (1968) discovered that a wide range of alkylamines was present in different kinds of algae (in detail: rhodophyceen $=$ red algae; phaeophyceen $=$ brown algae and chlorophyceen $=$ green algae). In rhodophyceen, they also detected amino acid carboxylase, which converts specific neutral amino acids to amines. These enzymes are widely distributed in marine algal species and their high concentrations suggest that amine formation via decarboxylation of amino acids might substantially contribute to the abundance of primary marine amines (Hartmann, 1972). In the Cape Verdean seawater, a wide range of amino acids such as leucine, alanine, valine, glycine and phenyl alanine are present at similar (or higher) concentration ranges to amines (personal communication: Triesch et al., publication in preparation). However, formation of MMA (the only primary amine measured in this study) from glycine has not been reported to date and the degradation of TMA to DMA and MMA is an alternative formation pathway (Lidbury et al., 2014; Lidbury et al., 2015a, b). More measurements (e.g. specific enzymes) would be needed to elucidate the range of formation mechanisms of the methylamines.

It is likely that the cycling of amines in the ocean is related to a variety of biological and microbial parameters, which cannot be accounted for within the scope of the present study. Recently, Suleiman et al., (2016) showed that interactions between diatoms and heterotrophic bacteria can be important for marine amine cycling. In another study, Gibb et al., (1999b) found evidence for amine production via the phytoplankton group of dinoflagellates (together with diatoms). Measurements of the diagnostic pigments of dinoflagellates (e.g. peridin, Uitz et al., 2006) have, however, not been included in the present study. Moreover, it has to be considered that, in the present study, chl-a and pigment concentration measurements could be obtained only from bulk water measurements, but amine concentrations were observed almost exclusively in the SML. It had been reported that the SML neuston community can differ from the community in bulk water (e.g. Cunliffe et al., 2011. Therefore, it would surely be beneficial to include biological measurements (phytoplankton and bacteria parameters) directly from the SML in future studies. This would also help to answer the question of whether the amines are formed in the SML or transported to the ocean surface from the underlying water.

Such measurements are challenging due to the limited sample availability of SML volume, at least with manual sampling techniques, and at difficult (stormy) sampling conditions. Nevertheless, studying bacteria and algal species explicitly in the SML should to be tackled in future research for understanding the biogeochemical cycle of amines in the ocean.

\subsubsection{Amines in the atmosphere}

Table 2 lists the amine concentrations in the gas and the particulate phases together with chl-a, wind speed, and particulate ammonium and sulfate concentration from the two intensive campaigns in 2011 and 2013. Both sampling times can be regarded as clean marine case studies, since the back trajectories had a very high residence time over the ocean. Furthermore, the concentrations of elemental carbon and calcium (tracers for anthropogenic influence and dust events, respectively) were generally low and consistent with marine measurements (more 
details and the corresponding data can be found in van Pinxteren et al., 2017). Table 2 shows that the amines were present in both the gaseous and particulate phase, respectively, at the same order of magnitude.

Concentrations of MMA ranged from $0.2 \mathrm{ng} \mathrm{m}^{-3}(0.2 \mathrm{ppt})$ to $1.8 \mathrm{ng} \mathrm{m}^{-3}$ (1.4 ppt) with an average of $0.8 \mathrm{ng} \mathrm{m}^{-3}(0.6 \mathrm{ppt})$ in the gas phase, and from $0 \mathrm{ng} \mathrm{m}^{-3}$ to $0.6 \mathrm{ng} \mathrm{m}^{-3}$ (average: $\left.0.2 \mathrm{ng} \mathrm{m}^{-3}\right)$ in the particle phase. The DMA concentrations ranged from $0.8 \mathrm{ng} \mathrm{m}^{-3}(0.4 \mathrm{ppt})$ to $19.2 \mathrm{ng} \mathrm{m}^{-3}$ (10 ppt) with an average of $4.5 \mathrm{ng} \mathrm{m}^{-3}$ (2.4 ppt) in the gas phase, and from $2.2 \mathrm{ng}$ $\mathrm{m}^{-3}$ to $13 \mathrm{ng} \mathrm{m}^{-3}$ (average: $5.6 \mathrm{ng} \mathrm{m}^{-3}$ ) in the particle phase. The sum of the amine concentrations in the particulate phase was not significantly different between these two campaigns (one-way anova, $p=0.12$ ). In the gas phase, however, the amine concentration was significant different (one-way anova, $\mathrm{p}=6.2 \mathrm{E}-5$ ), being higher in 2013 (Fig. 2). The measured gas-phase concentrations of DMA during the 2013 campaign were above 3 ppt. Almeida et al., (2013) found that, if DMA reaches gaseous concentrations of $3 \mathrm{ppt}$, new particle formation rates with sulfuric acid are enhanced 1000-fold compared with ammonia. Consequently, these results suggest that DMA could be very important for initialising particle nucleation in the marine boundary layer.

The concentration ranges of gas and particulate amines agreed well with amine measurements in other marine regions, such as the Bay of Bengal (Gibb et al., 1999a). In the particulate phase the amines contributed, on average, $5 \%(\min 2 \%$, max. $13 \%)$ to the water soluble organic carbon content, which is within the same order of magnitude as previous studies (Facchini et al., 2008), and confirms that these basic compounds comprise a substantial fraction of submicron water soluble organic carbon.

The gas phase amines (i.e. MMA and DMA) were strongly correlated to both chl-a and to the pigment fucoxanthin (Fig. 3a,b). This observation agreed well with the correlation between the amines and the biological indicators in seawater (Section 3.1.1). Correlating the amine concentrations in seawater with their gas phase concentrations showed a mild positive trend $\left(R^{2}=0.37\right.$, Fig. S2). Again, based on a very small number of SML data points and pvalues of 0.15 this correlation was statistically not significant at a significance level of $\alpha=0.05$. However, the visual trend that is observable in Fig. S2, indicates that the variability in the gas phase slightly followed the variability in the seawater. Amines are short-lived in the gas phase; their lifetimes with respect to the hydroxyl radical reaction are in the order of hours (Nielsen et al., 2012). Therefore, their link to the biological tracers chl-a and fucoxanthin suggests that their formation process and transfer to the gas phase are at least in part linked to marine (diatom) productivity.

A mild correlation of the gaseous amines with wind speed and sodium (Fig 3c, d) was found. It is known that the SML is strongly pronounced during calm conditions and acts as a physical barrier, causing a damping of wave formation and reduced gas transfer (e.g. Liss and Duce, 1997; Cunliffe et al., 2013; Engel et al., 2017). During stronger winds, the SML coverage is usually less prominent, which may consequently enhance the transfer of the volatile amines from the water to the gas phase. In a previous study, van Pinxteren et al. (2012) reported that the transfer of amines to the atmosphere increased at higher wind speeds due to enhanced wave formation. These findings are in agreement with the present study, however, detailed mechanisms can not be concluded here. 
Gas phase amines were also correlated to solar radiation and particulate oxalate (Fig. $3 \mathrm{e}, \mathrm{f}$ ), the latter being a tracer for secondary organic aerosol (SOA) formation (van Pinxteren et al., 2014). This correlation suggests that formation of amines and their transfer to the gas phase is supported by photochemical processes, consistent with data reported by Facchini et al., (2008).

\subsubsection{Partitioning between gas and aerosol particle phase}

In this data set, both the gas and particulate phases were dominated by DMA and only traces of MMA with slightly higher concentrations in the gaseous phase. DEA was absent in the gas phase, which might be a consequence of its lower vapour pressure (boiling point, b.p.: $55{ }^{\circ} \mathrm{C}$ ) compared to the other amines measured (MMA: b.p.: $-6.3{ }^{\circ} \mathrm{C}$, DMA: b.p.: $7.4{ }^{\circ} \mathrm{C}$; (Weast, 1986)). This suggests that either DEA is transferred directly from the seawater to the aerosol particle phase (via primary processes such as bubble bursting) or that gaseous DEA is immediately scavenged by the aerosol particle phase. In laboratory studies it was observed that gaseous amines were irreversibly taken up into a sulfuric acid solution (mimicking acidic aerosol particles) with the highest uptake coefficient recorded for DEA (Shi et al., 2011). This indicates that DEA, especially, can be rapidly transferred from the gaseous to particulate phase. In the present study, the molar ratio of ammonium to sulfate was always below two (Table 2), suggesting that sulfate in the aerosol particles was not completely neutralized by ammonium and that the particles were acidic, favouring a rapid transfer of DEA from the gaseous to the (acidic) particle phase.

In acidic particles, the amines will be protonated and remain in the particle phase as sorbed compounds. Therefore, it would be expected that the more acidic the particles, the more amines partition in the particle phase (e.g. Pratt et al., 2009). Such observations were reported for the gas to particle partitioning of amines in continental areas with strong variations in particulate sulfate and pronounced changes in day and night temperatures (You et al., 2014; Pratt et al., 2009). In the present study, however, a correlation of particulate amines with sulfate concentrations or the molar ratio of ammonium to sulfate (as a tracer for particle acidity) was not apparent. Furthermore, the ratio between the particle and the gas phase amines was not correlated to sulfate. One explanation could be that the particulate amines participate in further reactions; for example, they may form aminium salts or salts with other organic acids or high molecular weight products and therefore resist extraction (Murphy et al., 2007). Such reactions might be different in the tropical marine region with little variation in temperature and humidity and a different aerosol composition compared to continental regions. To further elucidate the fate of the amines, their reaction products in the marine particles would need to be studied. However, there is to date a lack of parallel measurements of amines in the gas and particle phase in the remote marine environment and the relation to their respective aerosol characteristics (e.g. chemical composition and hygroscopicity). The amine concentrations reported here expand the still limited database of amines in the marine atmosphere; the characteristics of the particulate amines are further discussed in Section 3.2.

\subsubsection{Exchange of amines across the air-sea interface}


The exchange fluxes between sea and air were calculated applying the 'two-phase' resistance model of gas exchange (Liss and Slater, 1974). Concerning the measurements conducted here, six pairs of DMA and four pairs of MMA measurements in seawater and in the gas phase (performed at the same time period) were used. From the respective concentrations, the mass flux $\mathrm{F}$ was calculated (Equation 1). The input parameters were the concentrations in the seawater (SML and bulk water), and the wind speed (Table 3).

The calculated ocean-atmosphere mass fluxes $(F)$ are listed in Table 3 and ranged between $-1.9 \mathrm{E}-12$ and $+2.17 \mathrm{E}-12 \mathrm{~mol} \mathrm{~m}^{-2} \mathrm{~s}^{-1}$. The majority of the fluxes for MMA were positive, suggesting that in this area the ocean is a source of MMA. For DMA, however, the ratio between positive and negative fluxes is more balanced. This non-uniform trend suggests that the ocean can act as either a sink or a source for DMA. The calculated positive fluxes are one to two orders of magnitude lower as the global $\mathrm{NH}_{3}$ flux from the ocean, which ranges from $1.4 \mathrm{E}-11 \mathrm{~mol} \mathrm{~m}^{-2} \mathrm{~s}^{-1}$ to $3.2 \mathrm{E}-11 \mathrm{~mol} \mathrm{~m}^{-2} \mathrm{~s}^{-1}$ (Paulot et al., 2015). However, MMA and DMA can initialise much stronger nucleation rates than $\mathrm{NH}_{3}$. For example, in the laboratory work of Glasoe et al., (2015) it was shown that at the same gaseous sulfuric acid concentrations, 2 ppt

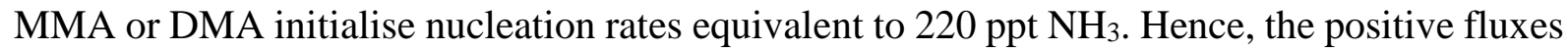
can be crucial for marine new particle formation at the measuring site. That the order of magnitude of the fluxes, as well as the discovery that the oceans could be either a source or a sink, is in agreement with previous findings by Gibb et al., (1999a). It is likely that the source/sink capabilities of the ocean vary due to different ambient conditions. For example, during midday, when radiation is highest and photochemistry is triggered, oxidation reactions in the atmosphere might occur that, in turn, affect the amine fluxes. In the following, such oxidation reactions are exemplarily illustrated for the reaction of the amines with $\mathrm{OH}$ radicals. Amines are known to react fast with $\mathrm{OH}$ radicals in the gas phase; the determined experimental rate coefficients for MMA are around 2.0E-11 cm $\mathrm{cm}^{3}$ molecules ${ }^{-1} \mathrm{~s}^{-1}$ and for DMA around 6.5E-11 $\mathrm{cm}^{3}$ molecules ${ }^{-1} \mathrm{~s}^{-1}$ (Nielsen et al., 2010). The global mean $\mathrm{OH}$ gas-phase concentration is 1.0E +6 molecules $\mathrm{cm}^{-3}$ (Finlayson-Pitts and Pitts, 2000). The corresponding calculated tropospheric lifetime is 14 and 4 hours for MMA and DMA, respectively. However, in the unpolluted marine boundary layer, the $\mathrm{OH}$ radical typically exhibits a diurnal behavior with measured maximum values in the range from 2.0 to $7.0 \mathrm{E}+6$ molecules $\mathrm{cm}^{-3}$ around noon (Heard and Pilling, 2003; Stone et al., 2012). Therefore, the oxidation by $\mathrm{OH}$ radicals is assumed to be much faster during midday resulting in a quick oxidation of MMA and DMA as well as other amines. Consequently, amine gas-phase concentrations and related amine emission fluxes are expected to show a diurnal concentration trend. Such diurnal variations could, however, not be captured in the present study as the gas phase concentrations consisted of gas phase measurements with a 24-hour average sampling time that was needed to meet the required sensitivity of the analytical measurements. To this end, analytical techniques with an enhanced sensitivity, as well as better time resolution e.g. through online (atmospheric) measurements of amines to investigate diurnal variability and diurnal fluxes, are highly desirable.

Another uncertainty in the flux calculation is that the transfer of the amines between the gaseous and the aerosol particle phase is not included in the gas exchange model, and the same holds true for wet deposition (though the latter one was mostly negligible at the sampling area).

To roughly estimate the potential total amount of amines in the atmosphere based on theoretical considerations, we used a simple approach including the pKa values of the amines, 
a typical liquid water content (LWC) and $\mathrm{pH}$-value of marine aerosol particles (Seinfeld and Pandis, 2006; Herrmann et al., 2015; Fallona, 2009). According to the equations 9-12 (listed in the Supplement), and applying the gas phase concentrations of MMA and DMA measured in the present study, we calculated the particulate aerosol concentration, assuming that the amines in the particle phase mainly originated from the gas phase and subsequent partitioning processes between the gas and particle phase. For a case study, we applied the average measured gas phase concentrations of MMA $\left(0.8 \mathrm{ng} \mathrm{m}^{-3}\right)$ and DMA $\left(4.5 \mathrm{ng} \mathrm{m}^{-3}\right)$ from this study, a LWC of $1 \mathrm{e}-4 \mathrm{~g} \mathrm{~m}^{-3}$ and a $\mathrm{pH}$-value of 4 (Herrmann et al., 2015; Fallona, 2009). The calculated aerosol concentrations were $0.8 \mathrm{ng} \mathrm{m}^{-3}$ for MMA and $3.3 \mathrm{ng} \mathrm{m}^{-3}$ for DMA resulting in a total amount of atmospheric amines of $1.6 \mathrm{ng} \mathrm{m}^{-3}$ for MMA and $7.8 \mathrm{ng} \mathrm{m}^{-3}$ for DMA. The calculated values are in the same order of magnitude compared to the ambient aerosol concentrations obtained from this study (listed in Table 2), indicating that the measured concentrations were plausible and that the transfer of amines from the gas phase could be an important source for the particulate amines. However, it has to be noted that this estimation is strongly affected by the LWC and the $\mathrm{pH}$-value and small changes in the input parameters can have a big effect on the results. A further, more detailed exploration of such calculations, including sensitivity and robustness tests, will be subject of future studies.

Despite these limitations, the data presented here support the still limited body of knowledge with respect to marine amine sea-air fluxes.

\subsection{4-month dataset of amines on aerosol particles}

\subsubsection{Observations}

While bulk seawater, SML and gas phase sampling could only be performed during the intensive measuring campaigns, aerosol particles at the CVAO were sampled continuously over the years 2012 and 2013, with a typical sampling time of 72 hours. These data were interpreted with respect to sources and characteristics of the particulate amines. Figure 4 illustrates the annual cycles of the particulate amine concentrations together with chl-a concentrations and sea surface temperature (SST). The amine concentrations within the 24-month were in the same order of magnitude with average values of $12 \mathrm{ng} \mathrm{m}^{-3}$ and $8 \mathrm{ng} \mathrm{m}^{-3}$ in 2012 and 2013, respectively. This is consistent with reported amine concentrations in the North Atlantic (Facchini et al., 2008). Müller et al., (2009) reported lower amine concentrations in aerosol particles at the CVAO; however, they only focused on particles sampled with an impactor in a very narrow size range from 0.14 to $0.42 \mu \mathrm{m}$. The composition of aliphatic amines changed during the 24-month of our observation period. While in 2012, both, DEA and DMA were the dominating amine species, in 2013 DEA was much less abundant and occurred only during the summer months in considerable concentrations (June /July 2013). This could be related to the significantly lower concentrations of DEA in the SML in 2013 compared to 2011.

The chl-a concentration is mostly low in this region (around $0.2 \mu \mathrm{g} \mathrm{L}^{-1}$ ), but within this 24-month observation period, some variation in the chl-a abundance was apparent, with two pronounced peaks in February 2012 and July 2013 (Fig. 4). These peaks in chl-a coincided with a lower sea surface temperature (SST). The lower SST could point to upwelling influences that potentially bring nutrient-rich water to the region of the CVAO and might trigger biological productivity in the ocean. However, upwelling influences, their seasonality and impacts on oceanic productivity are not well constrained for this region. Figure 4 shows that the particulate 
amine concentration partly coincided with the high chl-a/low SST period (February 2012). During other time series with high chl-a/low SST levels, no elevated response in the particulate amine concentrations was observed (July 2013). This ambivalent behaviour points to varying sources of the amines that might depend on the season. Another reason for this varying connection between chl-a and amine peaks could be a time lag between the oceanic productivity and the particulate amine abundance. Such delays between the production of biological material during high chl-a periods and their release and transfer to the particulate phase have been reported (O'Dowd et al., 2015). Furthermore, there might be other biological processes not reflected by chl-a which need to be considered for amine production.

The combination of the submicron particulate amine measurements with biogeochemical tracers from the 24-month time series revealed no clear connection of the amines to submicron non-sea salt calcium (dust tracer) and submicron non-sea salt sulfate (particle acidity tracer). In addition, correlations to submicron sodium and wind speed were absent. It may be that since wind speed data represented an average value of 72 hours, short but pronounced changes in the wind speed were not visible in the average wind speed value. However, Carpenter et al., (2010) showed that the wind speed generally exhibits strong and repetitive cycles within each 72 hour period. Hence, temporary maxima in wind speed are similarly represented in each 72 hour mean value. Sodium mass is more pronounced in the bigger aerosol particles and therefore acts as a more robust sea salt tracer when measured in the supermicron aerosol particles. However, O’Dowd et al. (1993) presented evidence for wind-speed-related submicron sea salt aerosol production. Therefore, we conclude that the missing connections of submicron particulate amines to wind and sodium imply that wind-mediated processes, such as bubble-bursting, may not dominantly determine the direct transfer of amines to the particulate phase. More likely, wind affects transfer of amines to the gas phase (Section 3.1.2), but does not impact the amines' distribution between the gas and the particulate phase.

\subsubsection{Statistical source attribution of the submicron particulate amines}

A principal component analysis (PCA) was applied to the 24-month dataset of particulate amines as a statistical procedure to qualitatively explore the potential sources of the particulate amines. All key parameters, as listed in Table 4, were included in the PCA to support the interpretation of the principal components: elemental carbon (EC) for primary anthropogenic influences, WSOC for anthropogenic and biogenic organic emissions, non-sea salt sulfate (non-ss sulfate), oxalate and ammonium as secondary aerosol formation tracers, as well as submicron potassium as a tracer for biomass burning. Chloride and sodium serve as tracers for sea spray emission and non-ss calcium as a tracer for desert dust. From the back trajectory analysis, the relative residence time over bare areas and the sunflux (solar irradiance) at the receptor site were included. Additionally, data for chl-a as a biological tracer was included in the PCA. The data were log transformed, mean-centered and scaled to unit variance. The principal components, were calculated from the correlation matrix. The number of factors to extract from the PCA was defined by examining the scree plots of eigenvalues (Figure S3) for the number of principal components. Varimax rotation was applied to the extracted principal components to result in rotated components with easier-to interpret component loadings (more details in Jolliffe, 2002). Five factors were selected from the scree analysis, in sum explaining $71 \%$ of the total data variance. Table 4 shows the loadings of the variables on the five rotated 
components, which describe the correlation of the variable and the component. Loadings below 0.2 are regarded as insignificant and thus not shown and loadings above 0.6 are printed in bold.

The first rotated component (Factor 1) explained $18 \%$ of the total variance of the dataset. This factor strongly correlated with ammonium, non-ss sulfate and the sunflux and likely represents a photochemical source, probably attributed to secondary aerosol formation. Factor 2 described $17 \%$ of the total data set variance. The factor strongly correlated with EC, non-ss calcium, potassium and the relative residence time over bare areas (desert) and might therefore represent a continental long-range factor, with contribution from biomass burning and the desert. Factor 2 also correlated to chl-a, which might be an indication for dust input in the ocean and a corresponding biological response. The third loaded component (Factor 3 ) also described $17 \%$ of the total dataset variance. Due to the high loading of sodium and chloride, this factor could mainly be attributed to sea salt emissions.

Factor 4 and Factor 5 are the factors that correlated with the particulate amines and explained $10 \%$ and $9 \%$ of the total dataset variance, respectively. Factor 4 correlated to DMA and DEA and showed no pronounced correlation to the other parameters investigated in the PCA. Factor 5 had a high loading of MMA and furthermore slightly correlated with WSOC. The finding that the amines appeared as separate factors in the PCA and their missing correlation to Factors $1-3$ suggested that the particulate amines could not directly be attributed to a photochemical, a continental or a sea salt (bubble-bursting) source. The absence of a correlation between DEA and Factor 3 (sea salt) suggested that bubble-bursting (formation of sea spray aerosol) is not the dominant transfer mechanism for DEA from the ocean to the atmosphere. More likely is that DEA is scavenged from the gas phase by the aerosol phase (as suggested in Sections 3.1.3 and 3.2.1). The results are in agreement with the study of Facchini et al. (2008) who observed that in freshly produced sea spray aerosol particles, the concentrations of DMA and DEA were always below the detection limit, excluding the existence of an important primary sea spray source. The results of the present study furthermore indicate that DMA and DEA were connected in their sources, whereas MMA had a different origin. Altogether, the results suggest that primary processes were not the main transfer mechanism for submicron particulate amines and, more likely, the partitioning between the gas and particle phase explained their abundance in marine aerosol particles. However, distinct sources or formation mechanisms of the submicron particulate amines remain unclear and need to be elucidated in future studies.

\section{Summary and Conclusion}

Within this study, the roles of the low molecular aliphatic amines MMA, DMA and DEA in the tropical marine environment were investigated. The amines were measured in all relevant marine compartments, the bulk seawater, the SML, the gas and the submicron aerosol phase; precipitation is mostly absent is this region. In seawater, the amines were almost exclusively detected in the SML, leaving the question open: are the amines formed at the ocean surface or transported there due to physical processes (e.g. rising bubbles). Amines in the SML and in the gas phase both showed a positive correlation towards biological (phytoplankton) indicators which suggested close linkage and indicated that the amine abundance in the atmosphere (gas phase) partly reflected biological processes in seawater. Future studies should 
include additional phytoplankton as well as bacterial parameters, preferably directly from the SML, for a more comprehensive understanding of the biogeochemical cycle of amines in the ocean. Sea to air fluxes of MMA and DMA varied between $-8.7 \mathrm{E}-14$ to $+4.0 \mathrm{E}-13 \mathrm{~mol} \mathrm{~m}^{-2} \mathrm{~s}^{-1}$ and $-1.9 \mathrm{E}-12$ to $+2.19 \mathrm{E}-12 \mathrm{~mol} \mathrm{~m}^{-2} \mathrm{~s}^{-1}$ respectively. This suggests that the ocean can act as a sink (negative flux) or, especially for MMA, as a source (positive flux) for the amines. The positive fluxes can be crucial for marine new particle formation at the measuring site.

It is likely that the source/sink capabilities of the ocean vary due to different ambient conditions such as a diurnal oxidation capacity of the atmosphere. To investigate the air-sea exchange of amines further, atmospheric measurements with a high spatial resolution and diurnal investigation of the amines in the gaseous phase and in the aerosol phase, as well as size-segregated aerosol sampling are required.

In contrast to the seawater and gas phase amines, no biological response was observed for the particle phase amines. The combination of the particulate amine measurements with biogeochemical tracers confirmed that a direct link from the amines to chl-a was missing. High amine concentrations coincided with high chl-a concentrations in winter; however, in summer, lower amine concentrations were observed at high chl-a peaks. No correlations of particulate amines to submicron calcium (dust tracer) and submicron sulfate (particle acidity tracer) were found. In addition, a correlation to submicron sodium and wind speed was absent, implying that wind-mediated processes such as bubble-bursting were not essential for the transfer of amines. A statistical source apportionment approach (PCA) revealed that the particulate amines are not correlated to the sources identified here, namely (1) photochemical formation, (2) continental/desert transport and (3) sea spray/bubble-bursting transfer. Furthermore, particulate DMA and DEA appeared to have a similar origin, whereas particulate MMA had a different source. Based on the results, we suggest that the amines are rather scavenged from the gas phase by the particle phase and bubble-bursting (formation of sea spray aerosol) is not the main transfer mechanism for amines moving from the ocean to the atmosphere.

Although, the number of seawater samples was limited (14 samples consisting of SML and bulk water, with detectable amine concentrations in 8 samples) these results are still a contribution to reduce the gap of knowledge about amines in the marine environment. Beyond that, it could be shown that aliphatic amines were present as a source of atmospheric base in the remote, often oligotrophic, region of the Cape Verde islands in all marine compartments. Their particulate concentrations showed strong temporal and interannual variations relating to several little understood factors, including gas to particle phase partitioning, long-range transport, ocean bioproductivity, air-sea exchange and photochemistry. In the submicron particulate phase especially, the amines contributed $5 \%$ on average to the water-soluble organic carbon pool and are, therefore, important constituents of the oceanic organic carbon and nitrogen cycle.

\section{Acknowledgements}

The authors would like to thank the technician of the CVAO station, Luis Neves, for his strong support within the field campaigns. We thank Katie Read for providing wind data from the Davis weather station at CVAO. For technical assistance we thank René Rabe, Susanne Fuchs, Anett Dietze, Marina Voyevoda, Sontje Krupka and Anke Roedger as well as Kerstin Lerche for chlorophyll-a and pigment analysis. Furthermore, the authors would like to thank the 
German Research Foundation (DFG) for funding within the ALAMARE and ALAMARE II projects (HE 3086/16-2). Manuela van Pinxteren and Nadja Triesch acknowledge the Leibniz Association SAW funding for the project "Marine biological production, organic aerosol particles and marine clouds: a Process Chain (MarParCloud)“, (SAW-2016-TROPOS-2) and for funding within the Research and Innovation Staff Exchange EU project MARSU (69089). Erik Hans Hoffmann wants to thank the Ph.D. scholarship program of the German Federal Environmental Foundation (Deutsche Bundestiftung Umwelt, DBU) for its financial support. Finally, the authors thank the anonymous reviewers for their valuable comments and suggestions. 
Table 1: Concentration of amines in the sea surface microlayer (SML) and in the bulk water in nmol $L^{-1}$, together with their enrichment factors (EF) in the SML

2 calculated as the quotient of the average amine concentration in the SML versus the amine concentration in the bulk water sample. Furthermore, the

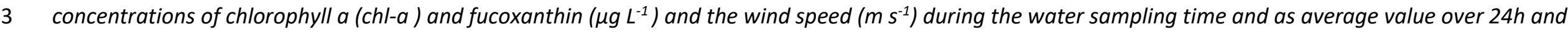
4 are listed.

\begin{tabular}{|c|c|c|c|c|c|c|c|c|c|}
\hline Sampling date & Water type & MMA & DMA & DEA & sum amines & chl-a* & fucoxanthin* & $\begin{array}{l}\text { wind speed } \\
\text { (during } \\
\text { sampling) }\end{array}$ & $\begin{array}{c}\text { wind speed } \\
\qquad(24 \mathrm{~h})\end{array}$ \\
\hline 11.11 .2011 & SML & 5 & 11 & 22 & 38 & 0.07 & 0.02 & 3 & 7 \\
\hline 14.11 .2011 & SML & 32 & 15 & 22 & 69 & 0.17 & 0.04 & 7 & 6 \\
\hline 20.11 .2011 & SML & 33 & 2 & 21 & 56 & 0.29 & 0.06 & 11 & 11 \\
\hline 22.11 .2011 & SML & 8 & 4 & 23 & 35 & 0.20 & 0.02 & 10 & 10 \\
\hline 12.11 .2013 & SML & 23 & 197 & 14 & 234 & 0.39 & 0.06 & 8 & 10 \\
\hline 13.11 .2013 & SML & 11 & 7 & 9 & 27 & 0.05 & $<$ LOD & 11 & 8 \\
\hline 19.11.2013 & SML & 20 & 135 & $<$ LOD & 155 & 0.19 & 0.19 & 11 & 11 \\
\hline 12.11 .2013 & Bulk & 19 & 28 & 10 & 57 & 0.39 & 0.06 & 8 & 10 \\
\hline average & - & 19 & 53 & 19 & 88 & 0.23 & 0.06 & 9 & 9 \\
\hline median & - & 20 & 11 & 22 & 56 & 0.20 & 0.06 & 9 & 10 \\
\hline minimum & - & 5 & 2 & 9 & 27 & 0.05 & 0.02 & 3 & 6 \\
\hline maximum & - & 33 & 197 & 23 & 234 & 0.39 & 0.19 & 11 & 11 \\
\hline
\end{tabular}

6 *Note that chl-a and fucoxanthin measurements were solely achieved from bulk water measurements, as stated in Section 2.1.1. 
Table 2: Concentration of amines in the gas and the particle phase $\left(\mathrm{ng} \mathrm{m}^{-3}\right)$, particulate ammonium, sulfate and sodium concentrations $\left(\mu \mathrm{g} \mathrm{m}^{-3}\right)$, the ratio of the 10 particle to the gas phase amines, the molar ratio of ammonium to sulfate, solar radiation $\left(\mathrm{W} \mathrm{m}^{-2}\right)$, particulate oxalate $\left(\mathrm{ng} \mathrm{m^{-3 }}\right)$, chl-a and fucoxanthin in 11 seawater $\left(\mu \mathrm{g} \mathrm{L}^{-1}\right)$ as well as air and sea surface (SST) temperature $\left({ }^{\circ} \mathrm{C}\right)$ and wind speed $\left(\mathrm{m} \mathrm{s}^{-1}\right)$.

\begin{tabular}{|c|c|c|c|c|c|c|c|c|c|c|c|c|c|c|c|c|c|c|c|c|c|c|}
\hline & & & phas & ni & & & e pr & an & & & & & & & & & & & & & & \\
\hline 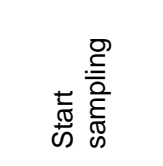 & 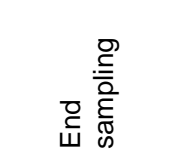 & $\sum_{\Sigma}^{\mathbb{\Sigma}}$ & $\sum_{0}^{\mathbb{L}}$ & 芯 & छ్ & $\sum_{\Sigma}^{\mathbb{K}}$ & $\sum_{\Delta}^{\mathbb{S}}$ & 㟧 & Е్ & 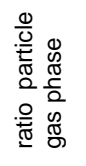 & $\frac{\stackrel{\Phi}{\frac{\pi}{5}}}{\frac{\bar{w}}{\bar{\omega}}}$ & 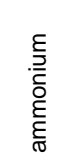 & 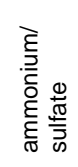 & 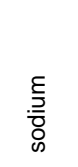 & 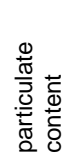 & 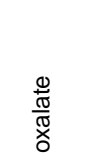 & 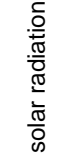 & 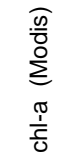 & 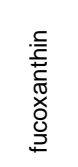 & 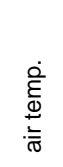 & $\begin{array}{c}5 \\
\infty\end{array}$ & $\begin{array}{l}\frac{8}{0} \\
\frac{0}{0} \\
\frac{0}{00} \\
\frac{0}{3}\end{array}$ \\
\hline 8.11 .2011 & 11.11 .2011 & $b$ & 2.0 & $a$ & 2.0 & 0.1 & 3.4 & 5.5 & 9.1 & 4.6 & 1.0 & 0.29 & 1.53 & 0.13 & 9.9 & 9.9 & 160 & 0.15 & $b$ & 24 & 25 & 6.8 \\
\hline 1.11 .2011 & 12.11 .2011 & $a$ & 1.1 & $a$ & 1.1 & 0.2 & 4.2 & 3.9 & 8.2 & 7.7 & 0.9 & 0.26 & 1.53 & 0.11 & 4.1 & 5.5 & 176 & 0.14 & 0.02 & 24 & 25 & .0 \\
\hline 2.11 .2011 & 13.11 .2011 & $a$ & 2.1 & $a$ & 2.1 & 0.0 & 4.5 & 5.6 & 10.2 & 4.9 & 0.7 & 0.24 & 1.70 & 0.08 & 6.5 & $a$ & 144 & 0.14 & $b$ & 24 & 26 & .0 \\
\hline 3.11 .2011 & 14.11 .2011 & $a$ & 1.3 & $a$ & 1.3 & 0.0 & 2.5 & 3.7 & 6.2 & 4.8 & 0.6 & 0.18 & 1.63 & 0.04 & 6.2 & 4.2 & 118 & 0.15 & $b$ & 24 & 25 & 8 \\
\hline 4.11 .2011 & 15.11 .2011 & $a$ & 1.4 & $a$ & 1.4 & 0.2 & 5.1 & 7.6 & 12.9 & 9.0 & 0.5 & 0.14 & 1.51 & 0.06 & 13.4 & 4.8 & 157 & 0.13 & 0.04 & 25 & 25 & 7.0 \\
\hline 5.11 .2011 & 16.11 .2011 & $a$ & 4.2 & $a$ & 4.2 & 0.2 & 2.6 & 5.1 & 7.9 & 1.9 & 0.6 & 0.16 & 1.48 & 0.08 & 6.9 & 10.2 & 126 & 0.16 & $b$ & 25 & 24 & 11.0 \\
\hline 6.11 .2011 & 17.11 .2011 & 0.6 & 2.4 & $a$ & 3.0 & 0 & 2.2 & 4.7 & 7. & 2.4 & 0.7 & 0 & 1.75 & 0.10 & 1.4 & $a$ & 143 & 0.18 & $b$ & 4 & 4 & 0 \\
\hline 7.11 .2011 & 18.11 .2011 & $a$ & 1.3 & $a$ & 1.3 & 0 & 4. & 5.2 & 9. & 7.6 & 0. & 0.25 & 1.61 & 0.08 & 2.3 & 6.8 & 150 & 0.17 & 0.05 & 24 & 25 & 6.0 \\
\hline 8.11 .2011 & 19.11 .2011 & 0.2 & 0.9 & $a$ & 1.2 & 0.2 & 6.9 & 9.1 & 16.2 & 13.9 & 0.9 & 0.27 & 1.60 & 0.07 & 4. & 5.7 & 153 & 0.14 & 0.05 & 24 & 24 & .0 \\
\hline 19.11.2011 & 20.11 .2011 & 0.6 & 1.9 & $a$ & 2.4 & 0.0 & 4.9 & 6.3 & 11.2 & 4.6 & 0.6 & 0.19 & 1.62 & 0.07 & 3.0 & 13.1 & 156 & 0.18 & $b$ & 24 & 24 & 11.0 \\
\hline 0.11 .2011 & 21.11 .2011 & $b$ & $b$ & $b$ & - & 0.2 & 6.0 & 5.5 & 11.7 & - & 0.4 & 01 & 1.42 & 0.14 & 2.7 & 11.4 & 154 & 0.18 & 0.06 & 4 & 24 & 9.4 \\
\hline 1.11 .2011 & 22.11 .2011 & $b$ & $b$ & $b$ & - & 0 & 5.5 & 5.4 & 11.1 & & 0 & 0.10 & 1.32 & 16 & 3.0 & 16.5 & 161 & 0.21 & 0.02 & 4 & 4 & 10.2 \\
\hline 2.11 .2011 & 23.11 .2011 & 0.7 & 4.5 & $a$ & 5.2 & 0.2 & 7.0 & 7.2 & 14.4 & 2.7 & 0.4 & 0.13 & 1.50 & 0.10 & 6.3 & 9.9 & 159 & 0.18 & $b$ & 24 & 24 & .8 \\
\hline 23.11.2011 & 24.11.2011 & 1.1 & 4.2 & $a$ & 5.3 & 0.2 & 6.1 & 4.4 & 10.7 & 2.0 & 0.4 & 0.11 & 1.50 & 0.15 & 3.6 & 2.0 & 150 & 0.20 & 0.02 & 24 & 24 & 8.6 \\
\hline
\end{tabular}




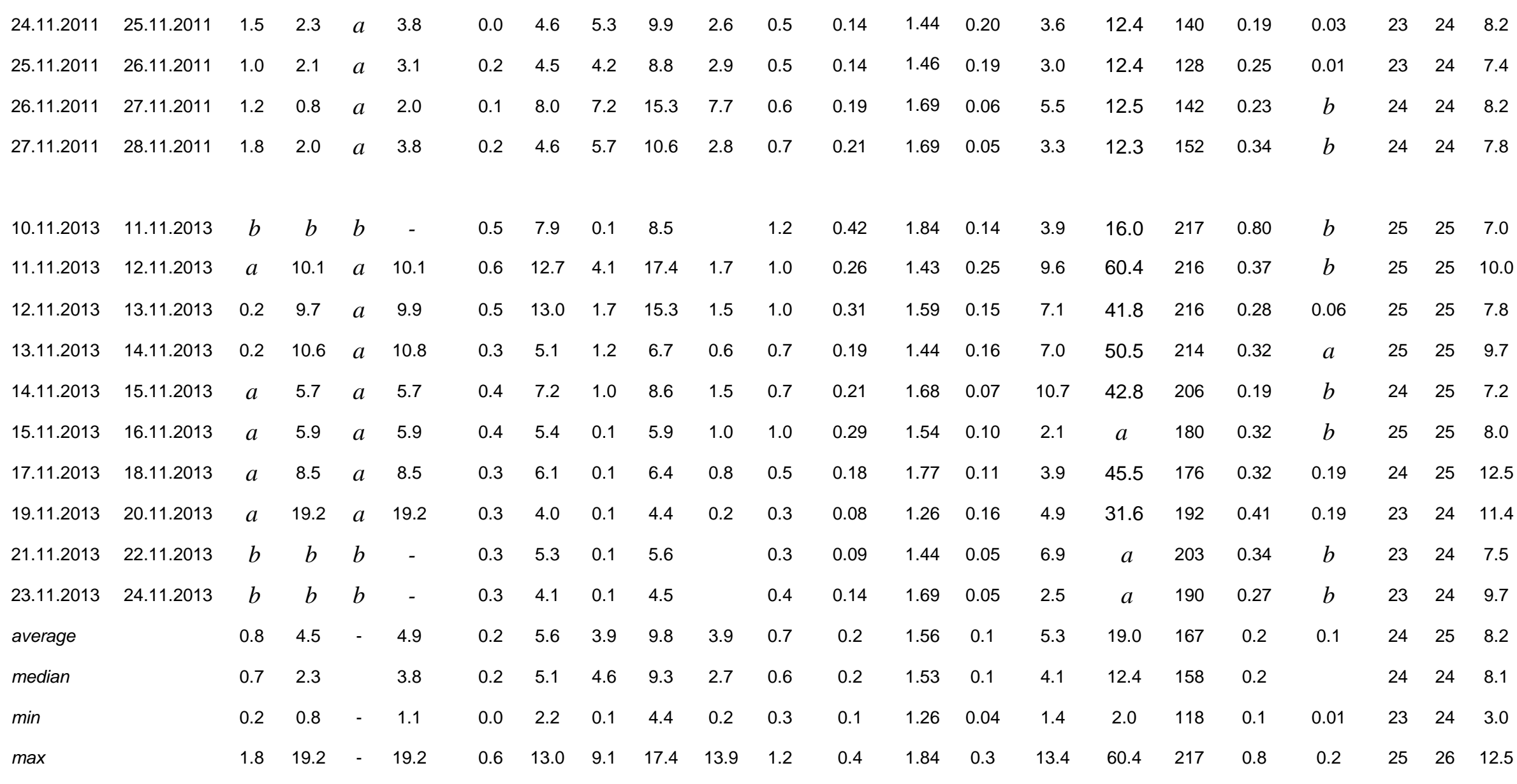

13

14 a below limit of detection. ${ }^{b}$ not measured

15 
Table 3: Seawater concentrations ( $\mathrm{nmol} \mathrm{L}^{-1}$ ) and gas phase concentrations $\left(\mathrm{ng} \mathrm{m}^{-3}\right)$ of DMA as well as the corresponding wind speed $u\left(\mathrm{~m} \mathrm{~s}^{-1}\right)$ and $u$, the drag coefficient after Johnsson et al., (2010) and the calculated sea-air flux (F) in mol $\mathrm{m}^{-2} \mathrm{~s}^{-1}$.

\begin{tabular}{|c|c|c|c|c|c|c|c|c|c|}
\hline \multirow[t]{2}{*}{$\begin{array}{l}\text { Sampling } \\
\text { date }\end{array}$} & \multicolumn{2}{|c|}{$\begin{array}{l}\text { Water } \\
\text { concentrations }\end{array}$} & \multicolumn{2}{|c|}{$\begin{array}{c}\text { Gas phase } \\
\text { concentrations }\end{array}$} & \multirow{2}{*}{$\begin{array}{l}\text { Wind } \\
\text { speed } \\
\text { u } 10\end{array}$} & \multirow{2}{*}{$\begin{array}{c}\text { Friction } \\
\text { velocity } \\
\mathrm{u}^{*}\end{array}$} & \multirow{2}{*}{$\begin{array}{l}\text { Drag } \\
\text { coefficient } \\
\text { CD }\end{array}$} & \multicolumn{2}{|c|}{$\begin{array}{c}\text { Sea-air flux } \\
\text { F }\end{array}$} \\
\hline & MMA & DMA & MMA & DMA & & & & MMA & DMA \\
\hline 11.11 .2011 & 5 & 11 & - & 1.1 & 3.0 & 0.0848 & 0.0008 & - & 2.6 E-15 \\
\hline 14.11 .2011 & 32 & 15 & - & 1.4 & 7.0 & 0.2269 & 0.0011 & - & 2.6 E-14 \\
\hline 20.11 .2011 & 33 & 2 & 0.6 & 1.9 & 11.0 & 0.3971 & 0.0013 & $4.0 \mathrm{E}-13$ & $-3.8 \mathrm{E}-13$ \\
\hline 22.11 .2011 & 8 & 4 & 0.7 & 4.5 & 9.8 & 0.3430 & 0.0012 & -8.7 E-14 & -8.1 E-13 \\
\hline 12.11 .2013 & 23 & 197 & 0.2 & 9.7 & 7.8 & 0.2589 & 0.0011 & $2.3 \mathrm{E}-13$ & 2.1 E-12 \\
\hline $\begin{array}{l}12.11 .2013 \\
\text { Bulk water }\end{array}$ & 19 & 28 & 0.2 & 9.7 & 7.8 & 0.2589 & 0.0011 & 1.9 E-13 & $-9.8 \mathrm{E}-13$ \\
\hline 13.11 .2013 & 11 & 7 & 0.2 & 10.6 & 9.7 & 0.3390 & 0.0012 & $9.5 \mathrm{E}-14$ & $-1.9 \mathrm{E}-12$ \\
\hline 19.11 .2013 & 20 & 135 & - & 19.2 & 11.4 & 0.4168 & 0.0013 & - & -1.2 E-12 \\
\hline
\end{tabular}


Table 4: PCA loadings after Varimax rotation. Loadings below 0.2 are not shown and high loadings above 0.6 are printed in bold red. All reported aerosol constituents were measured in the submicron mode.

\begin{tabular}{lccrrr}
\hline & $\begin{array}{c}\text { Factor 1 } \\
\text { photochemistry }\end{array}$ & $\begin{array}{c}\text { Factor 2 } \\
\text { continental }\end{array}$ & $\begin{array}{c}\text { Factor 3 } \\
\text { sea salt }\end{array}$ & $\begin{array}{r}\text { Factor 4 } \\
\text { amines I }\end{array}$ & $\begin{array}{r}\text { Factor 5 } \\
\text { amines II }\end{array}$ \\
\hline MMA & & & & 0.71 & 0.88 \\
DMA & 0.23 & & & 0.85 & \\
DEA & & & & 0.25 & \\
EC & 0.23 & 0.77 & & & \\
chloride & & & 0.92 & & \\
sodium & & & 0.91 & & \\
ammonium & 0.85 & & & & \\
non-ss sulfate & 0.87 & & & & \\
oxalate & 0.58 & 0.48 & 0.29 & & \\
non-ss calcium & & 0.63 & 0.53 & & \\
potassium & 0.3 & 0.6 & 0.42 & & \\
WSOC & 0.34 & 0.4 & & & \\
RT_bare areas & -0.3 & 0.65 & & & \\
sunflux at & 0.63 & -0.37 & & & \\
receptor & & 0.55 & & & \\
chl-a & & & & & \\
& & 0.17 & 0.17 & 0.1 & \\
variance & 0.18 & 0.17 &
\end{tabular}




\section{Figure Caption:}

Figure 1. Illustration of the filter pack applied for gas and particle phase amine sampling, designed after Gibb et al., (1999a). The filter pack consisted of a PTFE filter for particle phase amine sampling and a paper filter coated with $0.01 \mathrm{M}$ oxalic acid for gaseous amine sampling. A PTFE net was used to separate the aerosol particle and the gas phase filter.

Figure 2. Box and whisker plot of the concentrations of the gas phase amines $\left(\mathrm{ng} \mathrm{m}^{-3}\right)$ and the particle phase amines $\left(\mathrm{ng} \mathrm{m}^{-3}\right)$ in the two intensive campaigns. Each box encloses $50 \%$ of the data with the mean value represented as an open square and the median value represented as a line. The bottom of the box marks the $25 \%$ limit of the data, while the top marks the $75 \%$ limit. The lines extending from the top and bottom of each box are the 5\% and 95\% percentiles within the dataset, while the asterisks indicate the data points lying outside of this range ("outliers").

Figure 3. Correlations of the gas phase amines $\left(\mathrm{ng} \mathrm{m}^{-3}\right)$ to (a) chl-a $\left(\mu \mathrm{g} \mathrm{L}^{-1}\right)$, (b) fucoxanthin $\left(\mu \mathrm{g} \mathrm{L}^{-1}\right)$, (c) wind speed, (d) particulate sodium $\left(\mu \mathrm{g} \mathrm{m}^{-3}\right)$, (e) solar radiation $\left(\mathrm{W} \mathrm{m}^{2}\right)$ and (f) particulate oxalate $\left(\mu \mathrm{g} \mathrm{m}^{-3}\right)$.

Figure 4. Time series of the particulate amine concentrations $\left(\mathrm{ng} \mathrm{m}^{-3}\right)$ together with chl-a $(\mu \mathrm{g}$ $\left.\mathrm{L}^{-1}\right)$ and the $\mathrm{SST}\left({ }^{\circ} \mathrm{C}\right)$ for the 24-month time series. 
References

Almeida, J., Schobesberger, S., Kurten, A., Ortega, I. K., Kupiainen-Maatta, O., Praplan, A. P., Adamov, A., Amorim, A., Bianchi, F., Breitenlechner, M., David, A., Dommen, J., Donahue, N. M., Downard, A., Dunne, E., Duplissy, J., Ehrhart, S., Flagan, R. C., Franchin, A., Guida, R., Hakala, J., Hansel, A., Heinritzi, M., Henschel, H., Jokinen, T., Junninen, H., Kajos, M., Kangasluoma, J., Keskinen, H., Kupc, A., Kurten, T., Kvashin, A. N., Laaksonen, A., Lehtipalo, K., Leiminger, M., Leppa, J., Loukonen, V., Makhmutov, V., Mathot, S., McGrath, M. J., Nieminen, T., Olenius, T., Onnela, A., Petaja, T., Riccobono, F., Riipinen, I., Rissanen, M., Rondo, L., Ruuskanen, T., Santos, F. D., Sarnela, N., Schallhart, S., Schnitzhofer, R., Seinfeld, J. H., Simon, M., Sipila, M., Stozhkov, Y., Stratmann, F., Tome, A., Trostl, J., Tsagkogeorgas, G., Vaattovaara, P., Viisanen, Y., Virtanen, A., Vrtala, A., Wagner, P. E., Weingartner, E., Wex, H., Williamson, C., Wimmer, D., Ye, P. L., Yli-Juuti, T., Carslaw, K. S., Kulmala, M., Curtius, J., Baltensperger, U., Worsnop, D. R., Vehkamaki, H., and Kirkby, J.: Molecular understanding of sulphuric acid-amine particle nucleation in the atmosphere, Nature, 502, 359-+, 10.1038/nature12663, 2013.

Beale, R., and Airs, R.: Quantification of glycine betaine, choline and trimethylamine N-oxide in seawater particulates: Minimisation of seawater associated ion suppression, Analytica Chimica Acta, 938, 114-122, 10.1016/j.aca.2016.07.016, 2016.

Burg, M. B., and Ferraris, J. D.: Intracellular organic osmolytes: Function and regulation, Journal of Biological Chemistry, 283, 7309-7313, 10.1074/jbc.R700042200, 2008.

Cantonati, M., Scola, S., Angeli, N., Guella, G., and Frassanito, R.: Environmental controls of epilithic diatom depth-distribution in an oligotrophic lake characterized by marked waterlevel fluctuations, European Journal of Phycology, 44, 15-29, 10.1080/09670260802079335, 2009.

Cape, J. N., Cornell, S. E., Jickells, T. D., and Nemitz, E.: Organic nitrogen in the atmosphere - Where does it come from? A review of sources and methods, Atmospheric Research, 102, 30-48, 10.1016/j.atmosres.2011.07.009, 2011.

Carpenter, L. J., Fleming, Z. L., Read, K. A., Lee, J. D., Moller, S. J., Hopkins, J. R., Purvis, R. M., Lewis, A. C., Muller, K., Heinold, B., Herrmann, H., Fomba, K. W., van Pinxteren, D., Muller, C., Tegen, I., Wiedensohler, A., Muller, T., Niedermeier, N., Achterberg, E. P., Patey, M. D., Kozlova, E. A., Heimann, M., Heard, D. E., Plane, J. M. C., Mahajan, A., Oetjen, H., Ingham, T., Stone, D., Whalley, L. K., Evans, M. J., Pilling, M. J., Leigh, R. J., Monks, P. S., Karunaharan, A., Vaughan, S., Arnold, S. R., Tschritter, J., Pohler, D., Friess, U., Holla, R., Mendes, L. M., Lopez, H., Faria, B., Manning, A. J., and Wallace, D. W. R.: Seasonal characteristics of tropical marine boundary layer air measured at the Cape Verde Atmospheric Observatory, Journal of Atmospheric Chemistry, 67, 87-140, 10.1007/s10874-011-9206-1, 2010 .

Carpenter, L. J., Archer, S. D., and Beale, R.: Ocean-atmosphere trace gas exchange, Chemical Society Reviews, 41, 10.1039/c2cs35121h, 2012. 
Chen, H. H., Ezell, M. J., Arquero, K. D., Varner, M. E., Dawson, M. L., Gerber, R. B., and Finlayson-Pitts, B. J.: New particle formation and growth from methanesulfonic acid, trimethylamine and water, Physical Chemistry Chemical Physics, 17, 13699-13709, $10.1039 / \mathrm{c} 5 \mathrm{cp} 00838 \mathrm{~g}, 2015$.

Chen, H. H., Varner, M. E., Gerber, R. B., and Finlayson-Pitts, B. J.: Reactions of Methanesulfonic Acid with Amines and Ammonia as a Source of New Particles in Air, Journal of Physical Chemistry B, 120, 1526-1536, 10.1021/acs.jpcb.5b07433, 2016.

Christensen, J. J., Izatt, R. M., Wrathall, D. P., and Hansen, L. D.: Thermodynamics of Proton Ionization in Dilute Aqueous Solution .Part XI. pK, $\Delta \mathrm{H}^{\circ}$, and $\Delta \mathrm{S}^{\circ}$ Values for Proton Ionization from Protonated Amines at $25^{\circ}$, J Chem Soc A, 1212-1223, 10.1039/j19690001212, 1969.

Cree, C. H. L., Airs, R., Archer, S. D., and Fitzsimons, M. F.: Measurement of methylamines in seawater using solid phase microextraction and gas chromatography, Limnol. Oceanogr. Meth., 16, 411-420, 10.1002/lom3.10255, 2018.

Cree, C. H. L. Distributions of glycine betaine and the methylamines in coastal waters: analytical developments and a seasonal study, PhD Thesis, University of Plymouth, UK. https://pearl.plymouth.ac.uk/handle/10026.1/3441

Cunliffe, M., Upstill-Goddard, R. C., and Murrell, J. C.: Microbiology of aquatic surface microlayers. FEMS Microbiol. Rev. 35, 233-246. doi: 10.1111/j.1574-6976.2010.00246.x, 2011.

Cunliffe, M., Engel, A., Frka, S., Gasparovic, B., Guitart, C., Murrell, J. C., Salter, M., Stolle, C., Upstill-Goddard, R., and Wurl, O.: Sea surface microlayers: A unified physicochemical and biological perspective of the air-ocean interface, Progress in Oceanography, 109, 104116, 10.1016/j.pocean.2012.08.004, 2013.

Cunliffe, M., and Wurl, O.: "Guide to best practices to study the ocean's surface", Occasional Publications of the Marine Biological Association of the United Kingdom (Plymouth, UK), 118 pp. , (http://www.mba.ac.uk/NMBL/). 2014.

Dall'Osto, M., Ceburnis, D., Monahan, C., Worsnop, D. R., Bialek, J., Kulmala, M., Kurten, T., Ehn, M., Wenger, J., Sodeau, J., Healy, R., and O'Dowd, C.: Nitrogenated and aliphatic organic vapors as possible drivers for marine secondary organic aerosol growth, Journal of Geophysical Research-Atmospheres, 117, D1231110.1029/2012jd017522, 2012.

Dall'Osto, M., Ovadnevaite, J., Paglione, M., Beddows, D. C. S., Ceburnis, D., Cree, C., Cortes, P., Zamanillo, M., Nunes, S. O., Perez, G. L., Ortega-Retuerta, E., Emelianov, M., Vaque, D., Marrase, C., Estrada, M., Sala, M. M., Vidal, M., Fitzsimons, M. F., Beale, R., Airs, R., Rinaldi, M., Decesari, S., Facchini, M. C., Harrison, R. M., O'Dowd, C., and Simo, R.: Antarctic sea ice region as a source of biogenic organic nitrogen in aerosols, Scientific Reports, 7, 10.1038/s41598-017-06188-x, 2017. 
de Leeuw, G., Andreas, E. L., Anguelova, M. D., Fairall, C. W., Lewis, E. R., O'Dowd, C., Schulz, M., and Schwartz, S. E.: Production Flux of Sea Spray Aerosol, Reviews of Geophysics, 49, 10.1029/2010rg000349, 2011.

Draxier, R. R., and Hess, G. D.: An overview of the HYSPLIT_4 modelling system for trajectories, dispersion and deposition, Australian Meteorological Magazine, 47, 295-308, 1998.

Engel, A., Bange, H., Cunliffe, M., Burrows, S., Friedrichs, G., Galgani, L., Herrmann, H., Hertkorn, N., Johnson, M., Liss, P., Quinn, P., Schartau, M., Soloviev, A., Stolle, C., UpstillGoddard, R., van Pinxteren, M., and Zäncker, B.: The Ocean's Vital Skin: Toward an Integrated Understanding of the Sea Surface Microlayer, Front. Mar. Sci., 4, doi: 10.3389/fmars.2017.00165, 2017.

Facchini, M. C., Decesari, S., Rinaldi, M., Carbone, C., Finessi, E., Mircea, M., Fuzzi, S., Moretti, F., Tagliavini, E., Ceburnis, D., and O'Dowd, C. D.: Important Source of Marine Secondary Organic Aerosol from Biogenic Amines, Environmental Science \& Technology, 42, 9116-9121, 10.1021/es8018385, 2008.

Faloona, I.: Sulfur processing in the marine atmospheric boundary layer: A review and critical assessment of modeling uncertainties, Atmospheric Environment 43, 2841-2854, 2009.

Finessi, E., Decesari, S., Paglione, M., Giulianelli, L., Carbone, C., Gilardoni, S., Fuzzi, S., Saarikoski, S., Raatikainen, T., Hillamo, R., Allan, J., Mentel, T. F., Tiitta, P., Laaksonen, A., Petaja, T., Kulmala, M., Worsnop, D. R., and Facchini, M. C.: Determination of the biogenic secondary organic aerosol fraction in the boreal forest by NMR spectroscopy, Atmospheric Chemistry and Physics, 12, 941-959, 10.5194/acp-12-941-2012, 2012.

Finlayson-Pitts, B. J.: Pitts, J. N., Jr. Chemistry of the upper and lower atmosphere; Academic Press: San Diego, CA, p 328 10.1016/B978-012257060-5/50010-1, 2000.

Fomba, K. W., Müller, K., van Pinxteren, D., Poulain, L., van Pinxteren, M., and Herrmann, H.: Long-term chemical characterization of tropical and marine aerosols at the Cape Verde Atmospheric Observatory (CVAO) from 2007 to 2011, Atmospheric Chemistry and Physics, 14, 8883-8904, 10.5194/acp-14-8883-2014, 2014.

Fuller, E. N., Schettle.Pd, and Giddings, J. C.: A new method for prediction of binary gasphase diffusion coeffecients, Ind. Eng. Chem., 58, 19-27, 1966.

Ge, X. L., Wexler, A. S., and Clegg, S. L.: Atmospheric amines - Part I. A review, Atmospheric Environment, 45, 524-546, 10.1016/j.atmosenv.2010.10.012, 2011a.

Ge, X. L., Wexler, A. S., and Clegg, S. L.: Atmospheric amines - Part II. Thermodynamic properties and gas/particle partitioning, Atmospheric Environment, 45, 561-577, 10.1016/j.atmosenv.2010.10.013, 2011 b. 
Gibb, S. W., Mantoura, R. F. C., and Liss, P. S.: Ocean-atmosphere exchange and atmospheric speciation of ammonia and methylamines in the region of the NW Arabian Sea, Global Biogeochemical Cycles, 13, 161-177, 10.1029/98gb00743, 1999a.

Gibb, S. W., Mantoura, R. F. C., Liss, P. S., and Barlow, R. G.: Distributions and biogeochemistries of methylamines and ammonium in the Arabian Sea, Deep-Sea Research Part Ii-Topical Studies in Oceanography, 46, 593-615, 10.1016/s0967-0645(98)00119-2, 1999 b.

Glasoe, W. A., Volz, K., Panta, B., Freshour, N., Bachman, R., Hanson, D. R., McMurry, P. H., and Jen, C.: Sulfuric acid nucleation: An experimental study of the effect of seven bases, Journal of Geophysical Research: Atmospheres, 120, 1933-1950, 10.1002/2014jd022730, 2015 .

Hartmann, T.: Leucine carboxylase from marine rhodophyceae - appearance, distribution and some properties, Phytochemistry, 11, 1327-\&, 10.1016/s0031-9422(00)90081-5, 1972.

Heard, D. E., and Pilling, M. J.: Measurement of $\mathrm{OH}$ and $\mathrm{HO} 2$ in the Troposphere, Chem. Rev., 103, 5163-5198, 2003.

Herrmann, H., Schaefer, T., Tilgner, A., Styler, S. A., Weller, C., Teich, M., and Otto, T.: Tropospheric Aqueous-Phase Chemistry: Kinetics, Mechanisms, and Its Coupling to a Changing Gas Phase, Chem. Rev., 115, 4259-4334, 10.1021/cr500447k, 2015.

Jameson, E., Doxey, A. C., Airs, R., Purdy, K. J., Murrell, J. C., and Chen, Y.: Metagenomic data-mining reveals contrasting microbial populations responsible for trimethylamine formation in human gut and marine ecosystems, Microbial Genomics, 2, 10.1099/mgen.0.000080, 2016.

Jen, C. N., McMurry, P. H., and Hanson, D. R.: Stabilization of sulfuric acid dimers by ammonia, methylamine, dimethylamine, and trimethylamine, Journal of Geophysical Research: Atmospheres, 119, 7502-7514, 10.1002/2014jd021592, 2014.

Johnson, M. T.: A numerical scheme to calculate temperature and salinity dependent air-water transfer velocities for any gas, Ocean Science, 6, 913-932, 10.5194/os-6-913-2010, 2010.

Jolliffe, I. T.: Principal Component Analysis, in: Springer Series in Statistics, 2nd Edn., Springer, New York, 2002.

Khalil, M. A. K., Moore, R. M., Harper, D. B., Lobert, J. M., Erickson, D. J., Koropalov, V., Sturges, W. T., and Keene, W. C.: Natural emissions of chlorine-containing gases: Reactive Chlorine Emissions Inventory, Journal of Geophysical Research: Atmospheres, 104, 83338346, 10.1029/1998jd100079, 1999.

King, G. M.: Distribution and metabolism of quaternary amines in marine sediments, in: Nitrogen Cycling in Coastal Marine Environments, edited by: Sorenson, T. H. B. a. J., SCOPE 33 pp.143-175, 1988. 
Kurten, T., Loukonen, V., Vehkamaki, H., and Kulmala, M.: Amines are likely to enhance neutral and ion-induced sulfuric acid-water nucleation in the atmosphere more effectively than ammonia, Atmospheric Chemistry and Physics, 8, 4095-4103, 10.5194/acp-8-4095-2008, 2008.

Lee, D., and Wexler, A. S.: Atmospheric amines - Part III: Photochemistry and toxicity, Atmospheric Environment, 71, 95-103, 10.1016/j.atmosenv.2013.01.058, 2013.

Lidbury, I., Murrell, J. C., and Chen, Y.: Trimethylamine N-oxide metabolism by abundant marine heterotrophic bacteria, Proceedings of the National Academy of Sciences of the United States of America, 111, 2710-2715, 10.1073/pnas.1317834111, 2014.

Lidbury, I., Kimberley, G., Scanlan, D. J., Murrell, J. C., and Chen, Y.: Comparative genomics and mutagenesis analyses of choline metabolism in the marine Roseobacter clade, Environmental Microbiology, 17, 5048-5062, 10.1111/1462-2920.12943, 2015a.

Lidbury, I., Murrell, J. C., and Chen, Y.: Trimethylamine and trimethylamine N-oxide are supplementary energy sources for a marine heterotrophic bacterium: implications for marine carbon and nitrogen cycling, Isme Journal, 9, 760-769, 10.1038/ismej.2014.149, 2015b.

Liss, P. S., and Slater, P. G.: Flux of gases across ais-sea interface Nature, 247, 181-184, 10.1038/247181a0, 1974.

Liss, P. S., and Duce, R. A.: The Sea Surface and Global Change, edited by: Cambrigde University Press, C., 1997.

Miyazaki, Y., Kawamura, K., and Sawano, M.: Size distributions of organic nitrogen and carbon in remote marine aerosols: Evidence of marine biological origin based on their isotopic ratios, Geophysical Research Letters, 37, L0680310.1029/2010g1042483, 2010.

Müller, C., Iinuma, Y., Karstensen, J., van Pinxteren, D., Lehmann, S., Gnauk, T., and Herrmann, H.: Seasonal variation of aliphatic amines in marine sub-micrometer particles at the Cape Verde islands, Atmospheric Chemistry and Physics, 9, 9587-9597, 2009.

Müller, K., Lehmann, S., van Pinxteren, D., Gnauk, T., Niedermeier, N., Wiedensohler, A., and Herrmann, H.: Particle characterization at the Cape Verde atmospheric observatory during the 2007 RHaMBLe intensive, Atmospheric Chemistry and Physics, 10, 2709-2721, 2010 .

Murphy, S. M., Sorooshian, A., Kroll, J. H., Ng, N. L., Chhabra, P., Tong, C., Surratt, J. D., Knipping, E., Flagan, R. C., and Seinfeld, J. H.: Secondary aerosol formation from atmospheric reactions of aliphatic amines, Atmospheric Chemistry and Physics, 7, 2313-2337, 10.5194/acp-7-2313-2007, 2007.

Nielsen, C. J., Herrmann, H., Weller, C.: Atmospheric chemistry and environmental impact of the use of amines in carbon capture and storage (CCS), Chem. Soc. Rev., 41, 6684-6704, 2012 
Nightingale, P. D., Malin, G., Law, C. S., Watson, A. J., Liss, P. S., Liddicoat, M. I., Boutin, J., and Upstill-Goddard, R. C.: In situ evaluation of air-sea gas exchange parameterizations using novel conservative and volatile tracers, Global Biogeochemical Cycles, 14, 373-387, 10.1029/1999gb900091, 2000.

O'Dowd, C., Ceburnis, D., Ovadnevaite, J., Bialek, J., Stengel, D. B., Zacharias, M., Nitschke, U., Connan, S., Rinaldi, M., Fuzzi, S., Decesari, S., Facchini, M. C., Marullo, S., Santoleri, R., Dell'Anno, A., Corinaldesi, C., Tangherlini, M., and Danovaro, R.: Connecting marine productivity to sea-spray via nanoscale biological processes: Phytoplankton Dance or Death Disco?, Scientific Reports, 5, 10.1038/srep14883, 2015.

O'Dowd, C. D., Facchini, M. C., Cavalli, F., Ceburnis, D., Mircea, M., Decesari, S., Fuzzi, S., Yoon, Y. J., and Putaud, J. P.: Biogenically driven organic contribution to marine aerosol, Nature, 431, 676-680, Doi 10.1038/Nature02959, 2004.

O'Dowd, C. D., and Smith, M. H.: Physicochemical properties of aerosols over the northeast Atlantic: Evidence for wind-speed-related submicron sea-salt aerosol production, J. Geophys. Res.,98 (D1), 1137-1149, 1993

Paulot, F., Jacob, D. J., Johnson, M. T., Bell, T. G., Baker, A. R., Keene, W. C., Lima, I. D., Doney, S. C., and Stock, C. A.: Global oceanic emission of ammonia: Constraints from seawater and atmospheric observations, Global Biogeochemical Cycles, 29, 1165-1178, 10.1002/2015gb005106, 2015.

Pratt, K. A., Hatch, L. E., and Prather, K. A.: Seasonal Volatility Dependence of Ambient Particle Phase Amines, Environmental Science \& Technology, 43, 5276-5281, 10.1021/es803189n, 2009.

Quinn, P. K., Bates, T. S., Johnson, J. E., Covert, D. S., and Charlson, R. J.: Interactions between the sulfur and reduced nitrogen cycles over the central Pacific-Ocean, J. Geophys. Res.-Atmos., 95, 16405-16416, 10.1029/JD095iD10p16405, 1990.

Reinthaler, T.; Sintes, E.; Herndl, G. J.: Dissolved organic matter and bacterial production and respiration in the sea-surface microlayer of the open Atlantic and the western Mediterranean Sea. Limnol. Oceanogr., 53, (1), 122-136., 2008.

Seinfeld, J. H., and Pandis, S. N.: Atmospheric Chemistry and Physics, John Wiley \& Sons, Inc., Hoboken, New Jersey, USA, 2006.

Shi, Y., MaoFa, G., WeiGang, W., Ze, L., and DianXun, W.: Uptake of gas-phase alkyl amines by sulfuric acid Chinese Science Bulletin, 56, 1241-1245, 10.1007/s11434-010-433192011.

Steiner, M., and Hartmann, T.: Occurence and distribution of volatile amines in marine algae, Planta, 79, 113-\&, 10.1007/bf00390154, 1968. 
Stone, D., Whalley, L., K., and Heard ,D., E.: Tropospheric OH and HO2 radicals: field measurements and model, Comparisons, Chem. Soc. Rev., 41, 6348-6404, 2012

Suleiman, M., Zecher, K., Yucel, O., Jagmann, N., and Philipp, B.: Interkingdom CrossFeeding of Ammonium from Marine Methylamine-Degrading Bacteria to the Diatom Phaeodactylum tricornutum, Applied and Environmental Microbiology, 82, 7113-7122, 10.1128/aem.01642-16, 2016.

Taubert, M., Grob, C., Howat, A. M., Burns, O. J., Pratscher, J., Jehmlich, N., von Bergen, M., Richnow, H. H., Chen, Y., and Murrell, J. C.: Methylamine as a nitrogen source for microorganisms from a coastal marine environment, Environmental Microbiology, 19, 22462257, 10.1111/1462-2920.13709, 2017.

Uitz, J.,Claustre, H.,Morel, A., Hooker, S.B.:Vertical distribution of phytoplankton communities in open ocean: An assessment based on surface chlorophyll, J. Geophys. Res., 111, C08005, doi:10.1029/2005JC003207, 2006.van Pinxteren, D., Brueggemann, E., Gnauk, T., Mueller, K., Thiel, C., and Herrmann, H.: A GIS based approach to back trajectory analysis for the source apportionment of aerosol constituents and its first application, Journal of Atmospheric Chemistry, 67, 1-28, 10.1007/s10874-011-9199-9, 2010.

van Pinxteren D, Brueggemann E, Gnauk T, Mueller K, Thiel C, Herrmann, H.: A GIS based approach to back trajectory analysis for the source apportionment of aerosol constituents and its first application. Journal of Atmospheric Chemistry 67(1): 1-28. doi:10.1007/s10874-0119199-9, 2010.

van Pinxteren, D., Neususs, C., and Herrmann, H.: On the abundance and source contributions of dicarboxylic acids in size-resolved aerosol particles at continental sites in central Europe, Atmospheric Chemistry and Physics, 14, 3913-3928, 10.5194/acp-14-3913-2014, 2014.

van Pinxteren M, Müller C, Iinuma Y, Stolle C, Herrmann H.: Chemical characterization of dissolved organic compounds from coastal sea surface micro layers (Baltic Sea, Germany). Environmental Science and Technology 46(19): 10455-10462. doi:10.1021/es204492b, 2012

van Pinxteren, M., Fiedler, B., van Pinxteren, D., Iinuma, Y., Koertzinger, A., and Herrmann, H.: Chemical characterization of sub-micrometer aerosol particles in the tropical Atlantic Ocean: marine and biomass burning influences, Journal of Atmospheric Chemistry, 72, 105 125, 10.1007/s10874-015-9307-3, 2015.

van Pinxteren, M., Barthel, S., Fomba, K., Müller, K., von Tümpling, W., and Herrmann, H.: The influence of environmental drivers on the enrichment of organic carbon in the sea surface microlayer and in submicron aerosol particles - measurements from the Atlantic Ocean, Elem Sci Anth, 5, https://doi.org/10.1525/elementa.225, 2017.

Weast, R. C.: CRC Handbook of Chemistry and Physics, CRC Press, Boca Ratou, FL, 1986.

Xie, H., Feng, L. M., Hu, Q. J., Zhu, Y. J., Gao, H. W., Gao, Y., and Yao, X. H.: Concentration and size distribution of water-extracted dimethylaminium and 
trimethylaminium in atmospheric particles during nine campaigns - Implications for sources, phase states and formation pathways, Science of the Total Environment, 631-632, 130-141, 10.1016/j.scitotenv.2018.02.303, 2018.

You, Y., Kanawade, V. P., de Gouw, J. A., Guenther, A. B., Madronich, S., Sierra-Hernandez, M. R., Lawler, M., Smith, J. N., Takahama, S., Ruggeri, G., Koss, A., Olson, K., Baumann, K., Weber, R. J., Nenes, A., Guo, H., Edgerton, E. S., Porcelli, L., Brune, W. H., Goldstein, A. H., and Lee, S. H.: Atmospheric amines and ammonia measured with a chemical ionization mass spectrometer (CIMS), Atmospheric Chemistry and Physics, 14, 12181-12194, 10.5194/acp-14-12181-2014, 2014.

Yu, P. R., Hu, Q. J., Li, K., Zhu, Y. J., Liu, X. H., Gao, H. W., and Yao, X. H.:

Characteristics of dimethylaminium and trimethylaminium in atmospheric particles ranging from supermicron to nanometer sizes over eutrophic marginal seas of China and oligotrophic open oceans, Science of the Total Environment, 572, 813-824, 10.1016/j.scitotenv.2016.07.114, 2016. 